\title{
Thermal Mapping of Hawaiian Volcanoes with ASTER Satellite Data
}

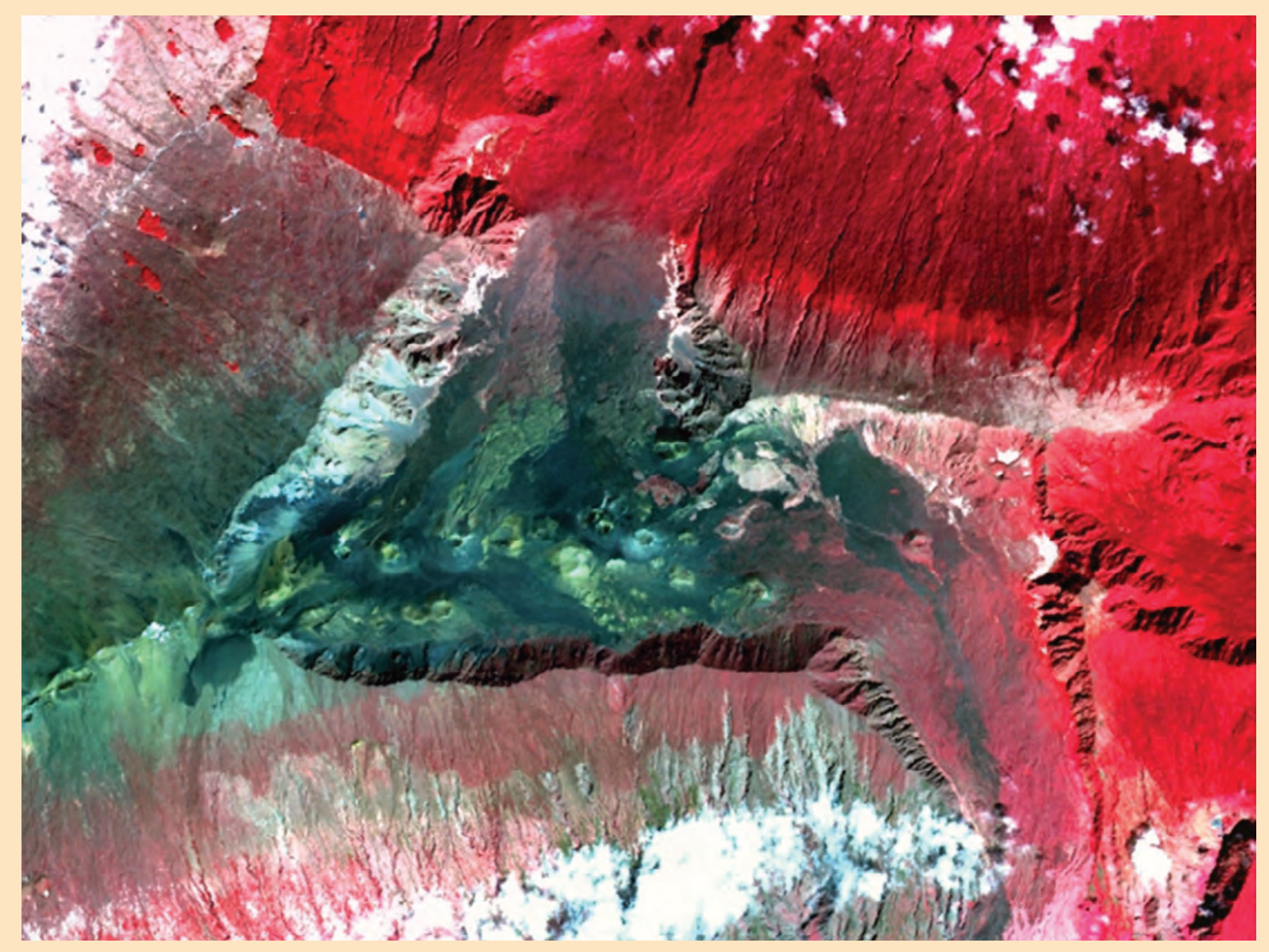

Scientific Investigations Report 2011-5110

U.S. Department of the Interior U.S. Geological Survey 


\section{FRONT COVER}

ASTER VNIR (visible and near-infrared) image of Haleakalā Volcano, Maui, Hawai'i. Area shown is about $15 \mathrm{~km}$ by $12 \mathrm{~km}$. 


\section{Thermal Mapping of Hawaiian Volcanoes with ASTER Satellite Data}

By Matthew R. Patrick and Coral-Nadine Witzke

Scientific Investigations Report 2011-5110 


\section{U.S. Department of the Interior KEN SALAZAR, Secretary}

\section{U.S. Geological Survey Marcia K. McNutt, Director}

\section{U.S. Geological Survey, Reston, Virginia: 2011}

This report and any updates to it are available online at:

http://pubs.usgs.gov/sir/2011/5110/

For more information on the USGS - the Federal source for science about the Earth, its natural and living resources, natural hazards, and the environment:

World Wide Web: http://www.usgs.gov/

Telephone: 1-888-ASK-USGS

Any use of trade, product, or firm names in this publication is for descriptive purposes only and does not imply endorsement by the U.S. Government.

Although this report is in the public domain, it may contain copyrighted materials that are noted in the text. Permission to reproduce those items must be secured from the individual copyright owners.

Cataloging-in-Publication data are on file with the Library of Congress (URL http://www.loc.gov/).

Suggested citation:

Patrick, M.R., and Witzke, C.-N., 2011, Thermal mapping of Hawaiian volcanoes with ASTER

satellite data: U.S. Geological Survey Scientific Investigations Report 2011-5110, 22 p. 


\section{Contents}

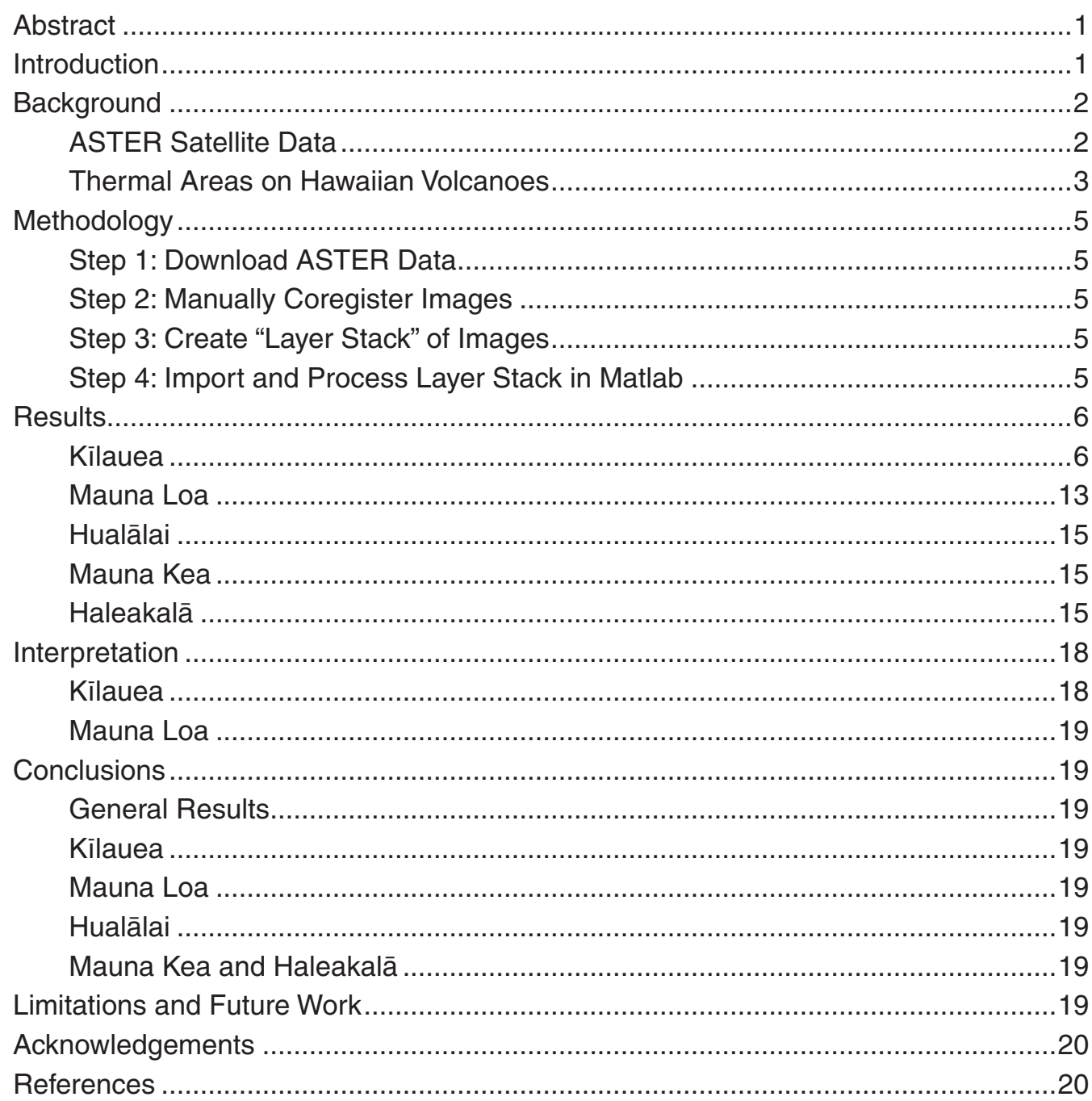

\section{Figures}

1. Map of the islands forming the southeastern end of the Hawaiian Island chain

2. Maps and images from earlier studies of thermal features at Kilauea's summit

3. ASTER VNIR image and surface kinetic temperature map of Kìlauea's caldera

4. Surface kinetic temperature map of Kìlauea's summit area.........................8

5. Standard deviation of surface temperature variation over time, Kilauea.........8

6. Comparison of present-day areas of alteration and deposition on the floor of Killauea caldera with surface temperatures ...........................9

7. Changes in temperature in several regions of interest at Killauea's summit, 2000 to 2010 
8. Trend of maximum temperature at the Halema'uma'u region of interest ......12

9. Single ASTER surface kinetic temperature image of much of Kïlauea Volcano 12

10. ASTER VNIR image and surface kinetic temperature map of Mauna Loa's summit caldera (Moku'āweoweo) and upper rift zones...................................13

11. Close-up views of Mauna Loa summit......................................................14

12. Enlargement of Mauna Loa temperature map with thermal areas labeled...14

13. Standard deviation of surface temperature variation over time, Mauna

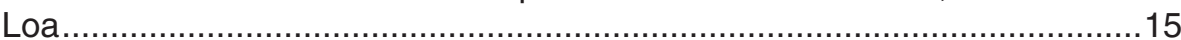

14. Changes in temperature in several regions of interest on Mauna Loa .........16

15. ASTER VNIR image and surface kinetic temperature map of Hualālai

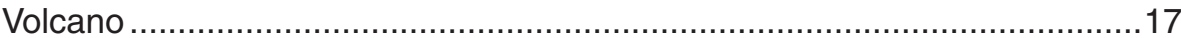

16. ASTER VNIR image and surface kinetic temperature map of Mauna Kea Volcano 17

17. ASTER VNIR image and surface kinetic temperature map of Haleakalā

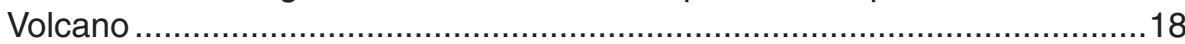

18. Current and past topography at Moku'āweoweo caldera, Mauna Loa..........20

\section{Tables}

1. Brief selection of thermal image surveys over volcanoes ..............................2 


\title{
Thermal Mapping of Hawaiian Volcanoes with ASTER Satellite Data
}

\author{
By Matthew R. Patrick ${ }^{1}$ and Coral-Nadine Witzke ${ }^{1,2}$
}

\section{Abstract}

Thermal mapping of volcanoes is important to determine baseline thermal behavior in order to judge future thermal activity that may precede an eruption. We used cloud-free kinetic temperature images from the ASTER (Advanced Spaceborne Thermal Emission and Reflection Radiometer) sensor obtained between 2000 and 2010 to produce thermal maps for all five subaerial volcanoes in Hawai' $i$ that have had eruptions in the Holocene (Kîlauea, Mauna Loa, Hualālai, Mauna Kea, and Haleakalā). We stacked the images to provide time-averaged thermal maps, as well as to analyze temperature trends through time. Thermal areas are conspicuous at the summits and rift zones of Killauea and Mauna Loa, and the summit calderas of these volcanoes contain obvious arcuate, concentric linear thermal areas that probably result from channeling of rising gas along buried, historical intracaldera scarps. The only significant change in thermal activity noted in the study period is the opening of the Halema'uma' $u$ vent at Killauea's summit in 2008. Several small thermal anomalies are coincident with pit craters on Hualālai. We suspect that these simply result from the sheltered nature of the depression, but closer inspection is warranted to determine if genuine thermal activity exists in the craters. Thermal areas were not detected on Haleakalā or Mauna Kea. The main limitation of the study is the large pixel size $(90 \mathrm{~m})$ of the ASTER images, which reduces our ability to detect subtle changes or to identify small, low-temperature thermal activity. This study, therefore, is meant to characterize the broad, large-scale thermal features on these volcanoes. Future work should study these thermal areas with thermal cameras and thermocouples, which have a greater ability to detect small, low-temperature thermal features.

\footnotetext{
${ }^{1}$ Hawaiian Volcano Observatory-U.S. Geological Survey, PO Box 51, Hawai'i National Park, HI, 96718

${ }^{2}$ Now at: Geologisch-Paläontologisches Institut, Universität Hamburg, Bundesstraße 5520146 Hamburg, Germany

Contact: Matthew Patrick, mpatrick@usgs.gov, 808-967-8861
}

\section{Introduction}

Mapping surface temperatures can provide insights into a volcano's activity state and eruptive potential. Surface temperature maps have been useful in many instances for characterizing intereruptive behavior, producing a valuable picture of baseline thermal activity against which future activity can be compared. Thermal image surveys (acquired either from the ground, air, or space) have been conducted on numerous volcanoes, going back in time to the 1960s, including volcanoes in the Cascades, Hawai'i, Yellowstone, Central America, Iceland, Italy, New Zealand, and Japan (table 1; for early reviews see Friedman and Williams, 1968; Birnie, 1973; and Francis, 1979,) .

Characterizing baseline thermal output is important, because anomalous thermal behavior can sometimes precede major eruptive events. Yokoyama (1964) reported that fumarole temperatures increased by $150^{\circ} \mathrm{C}$ during the two months before the 1962 explosive eruption at Tokachi, Japan. Infrared surveys at Mount St. Helens in the 2 months preceding the May 18, 1980, explosive eruption revealed an increasing abundance of thermal anomalies on the summit bulge caused by the opening of new cracks (Kieffer and others, 1981). During the 2002-2003 eruption crisis at Stromboli Volcano, thermal imagery showed hot cracks below the summit craters. These cracks outlined the subsequent failure scarp of a large landslide that triggered a small tsunami (Bonnaccorso and others, 2003). Two months before the October 1, 2005, explosive eruption of Santa Ana Volcano, El Salvador, we observed that fumarole temperatures increased sufficiently to produce incandescence and clear thermal anomalies in satellite images (author's unpublished data). Thermal images also appeared to show an increase in temperature at the Santa Ana fumarole field several days before the explosive eruption (Hernandez and others, 2007). On Mauna Loa, Lockwood and others (1987, their fig. 19.2) showed a photograph of a snow-free area at South Pit and Lua Hou in the months before the 1975 eruption; they noted that this area of heating might have been a precursor to the eruption, but without a baseline characterization of thermal activity, it was not possible to be certain.

Surface temperatures can be measured with a variety of tools, with each having its own limitation in spatial extent 
Table 1. Brief selection of thermal image surveys over volcanoes.

\begin{tabular}{|c|c|c|}
\hline Volcanic region & Acquisition & Reference \\
\hline Cascade range & Airborne & $\begin{array}{l}\text { Moxham and others, 1965; Moxham, 1970; } \\
\text { Eichelberger and others, 1976; Kieffer and } \\
\text { others,, } 1981\end{array}$ \\
\hline Hawaì i & Airborne & Fischer and others, 1964 \\
\hline Yellowstone & Airborne & Williams and others, 1976 \\
\hline Central America & Ground, Airborne & Birnie, 1973; Gawarecki and others, 1980 \\
\hline Iceland & Airborne & Friedman and others, 1969 \\
\hline Etna, Vulcano, Campei Flegrei & Airborne, Ground & $\begin{array}{l}\text { Tabbagh et al., 1987; Chiodini and others, } \\
\text { 2007; Harris and others, } 2009\end{array}$ \\
\hline New Zealand & Airborne & Mongillo and Wood, 1995 \\
\hline Kerguelen Islands & Airborne & Ballestracci and Nougier, 1984 \\
\hline Japan & Ground, Airborne & $\begin{array}{l}\text { Shimozuru and Kagiyama, 1978; } \\
\text { Kagiyama, 1981; Yuhara and others, 1981; } \\
\text { Matsushima and others, } 2003\end{array}$ \\
\hline
\end{tabular}

and accuracy. At one extreme, the most direct and accurate means of temperature measurement is physical contact with a thermocouple (see, for example, Harris and Maciejewski, 2000, at Vulcano, Italy). These spot measurements, however, are inherently sparse and time consuming. At the other extreme, satellite thermal images provide an instantaneous, large-scale, synoptic view of temperatures across a volcano, but their large pixel sizes (typically tens to hundreds of meters across) result in significant averaging and resulting inaccurate measurements of small targets. Thermal cameras are a compromise between these two extremes - they typically provide higher resolution images but can still cover relatively large areas.

In this study we show surface temperature maps produced from ASTER (Advanced Spaceborne Thermal Emission and Reflection Radiometer) satellite imagery for Kīlauea, Mauna Loa, Mauna Kea, Hualālai, and Haleakalā (fig. 1), the five subaerial Hawaiian volcanoes that have had eruptions during the Holocene (approximately the past 11,500 years). We focus on the volcanoes' summit regions and upper rift zones only. We chose ASTER satellite imagery because it is abundant (16day repeat period), readily available and free of charge over the United States and its territories and for approved users for other areas, and of sufficient spatial resolution (90-m thermal infrared pixel size) to map large-scale thermal features on these volcanoes. Our objective is to characterize the largescale surface temperature distribution on these volcanoes and thus provide a baseline for comparison and allow detection of future anomalous behavior. The pixel size of the images is not small enough to produce accurate temperatures at individual fumaroles, but we view this effort at mapping largescale features as a first step and a means to provide a broad thermal context for these volcanoes. Further work, using aerial thermal-camera images and thermocouple measurements, would be useful for smaller scale measurements of thermal features.

\section{Background}

\section{ASTER Satellite Data}

The ASTER sensor is on the polar-orbiting Terra spacecraft and has been operational since February 2000. It provides 15 bands ranging from visible to thermal infrared wavelengths, at pixel sizes of 15 to $90 \mathrm{~m}$ (Yamaguchi and others, 1998). The thermal infrared images (90-m pixel size) provide only at-sensor radiance in the lower level data products (Level 1B). We are interested in ground surface temperature (that is, kinetic temperature), however, and to calculate this value from at-sensor radiance requires correcting for several factors, including emissivity and atmospheric transmissivity. Level 2 data include a surface kinetic temperature product (AST08) that accounts for these factors using the emissivity-temperature separation method described in the ASTER Higher Level User Guide (see http:// asterweb.jpl.nasa.gov/documents.asp) and in Gillespie and others (1998). The method essentially uses all five thermal infrared bands to determine emissivity. The surface kinetic temperature image contains data in convenient units of 


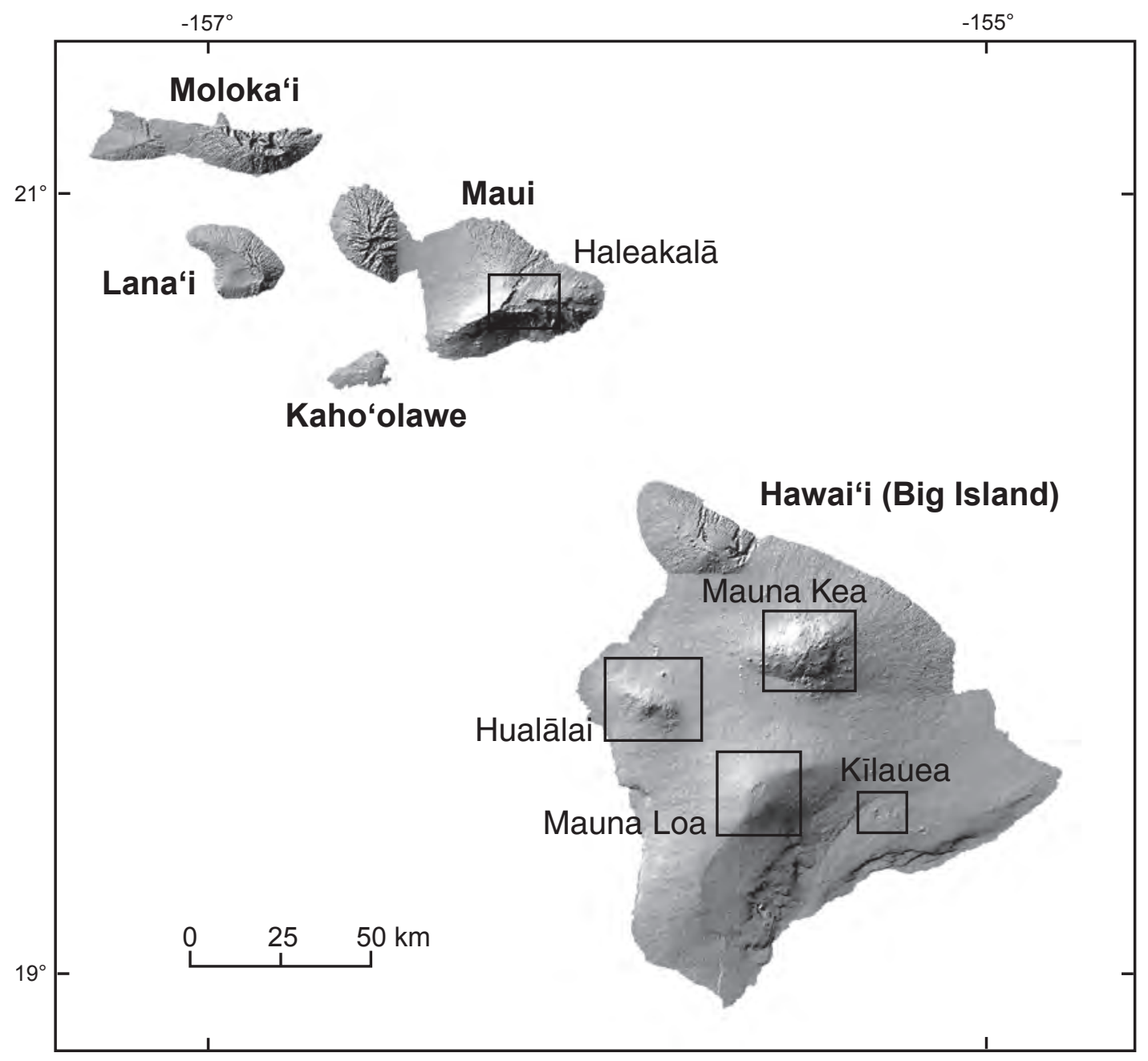

Figure 1. Map of the islands forming the southeastern end of the Hawaiian Island chain, showing the five volcanoes considered in this study. The boxes show the approximate areas covered by the ASTER thermal maps.

degrees kelvin (K), with a pixel size of $90 \mathrm{~m}$. The User Guide states that the absolute accuracy is $1-4 \mathrm{~K}$, with a relative accuracy of $0.3 \mathrm{~K}$.

It is vital to recognize that the temperature values in the ASTER images represent a spatial average over the area of the pixel $(90 \times 90 \mathrm{~m})$ and thus an underestimate, likely significant, of the maximum temperatures that may exist within the pixel footprint. For instance, a pixel may commonly cover a large area of ground at or near background temperature $\left(\sim 20^{\circ} \mathrm{C}\right)$ as well as very small areas of, say, fumaroles that are at a much higher temperature (for example, $>100^{\circ} \mathrm{C}$ ). The "pixelintegrated" temperature would normally be just slightly higher than background, because the hot source is small. Such pixels will still be conspicuous relative to background and can be useful for identification of anomalous thermal output. Therefore, we use the temperature values here to look at relative differences and to characterize large-scale changes across the volcano.

\section{Thermal Areas on Hawaiian Volcanoes}

Kilauea is currently experiencing two eruptions, the long-lived east rift zone eruption around $\mathrm{Pu}^{\prime} \mathrm{u}{ }^{‘} \overline{\mathrm{O}}^{‘} \overline{\mathrm{o}}$ that began in 1983 (Heliker and Mattox, 2003) and the summit eruption within a small vent in Halema'uma'u Crater that began in March 2008 (Wilson and others, 2008). Mauna Loa's last eruption was in 1984, from vents at the summit and northeast rift zone (Lockwood and others, 1987). Both Kîlauea and Mauna Loa host numerous thermal areas because of their shallow magmatic systems, with most such areas concentrated near the summits and rift zones. Several studies have characterized these areas (see Casadevall and Hazlett, 1983, for a review), and we focus on the summit regions. On Kilauea, Macdonald (1955) mapped areas of whitish fumarolic deposits on the floor of Killauea's caldera that corresponded to areas of visible steaming (fig. $2 A$ ). Macdonald speculated that the arcuate "narrow bands and irregular patches" of these 
deposits marked the buried margins of scarps that bounded the sunken basins on the caldera floor in the 1800s (fig. 2B). Jaggar (1938) described a probable intrusive event near Puhimau Crater that is thought to be related to the formation of the Puhimau thermal area (Hinkle, 1978; Conner, 1979; Casadevall and Hazlett, 1983), a region devoid of ohia trees that is currently $650 \times 350 \mathrm{~m}$ in size. The region has grown over the years; Hinkle (1978) shows the area was $500 \times 300 \mathrm{~m}$ in the late 1970s, and it had not yet reached the Chain of Craters road, as it does now. Aerial infrared surveys began in the 1960s, including that of Fischer and others (1964), which created thermal maps of Kïlauea's summit and rift zones and explored
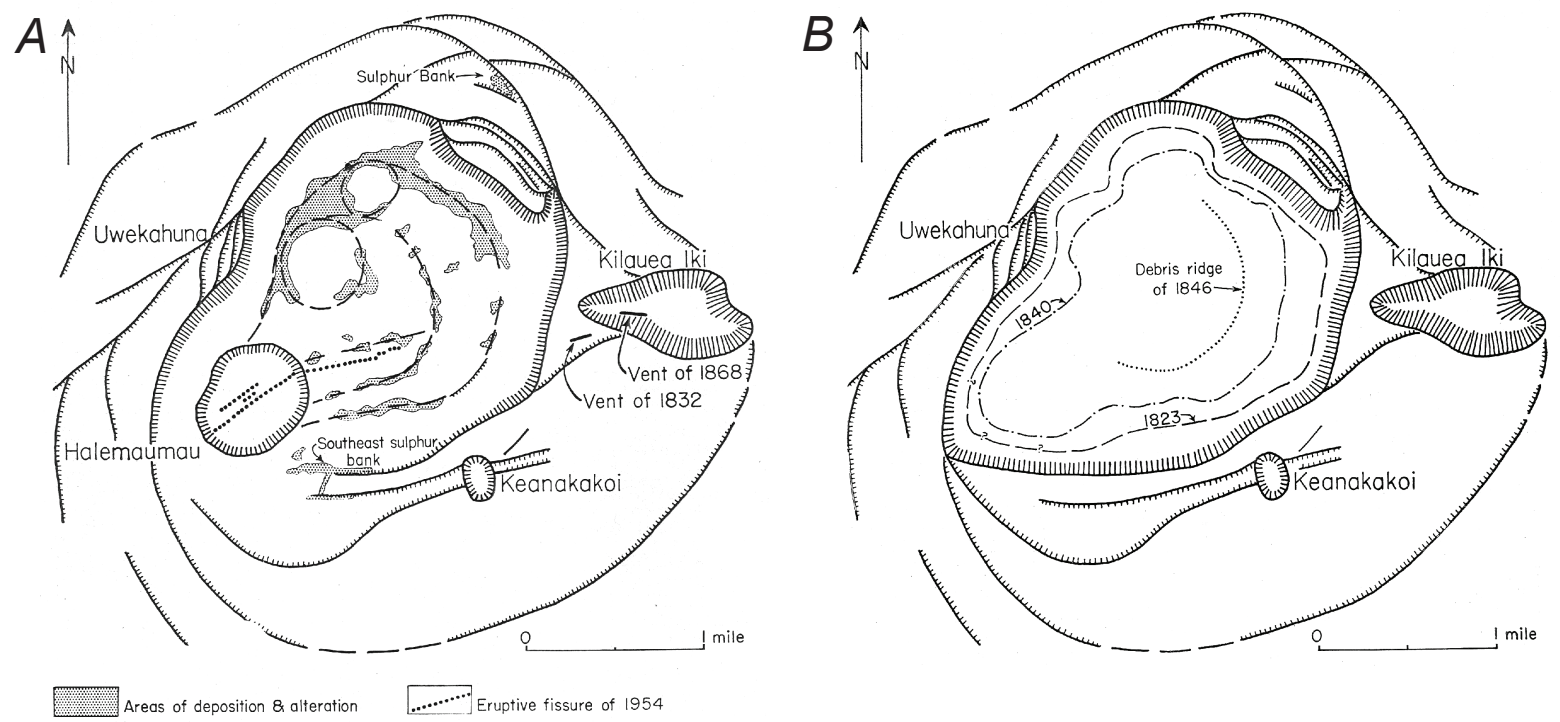

\section{C}
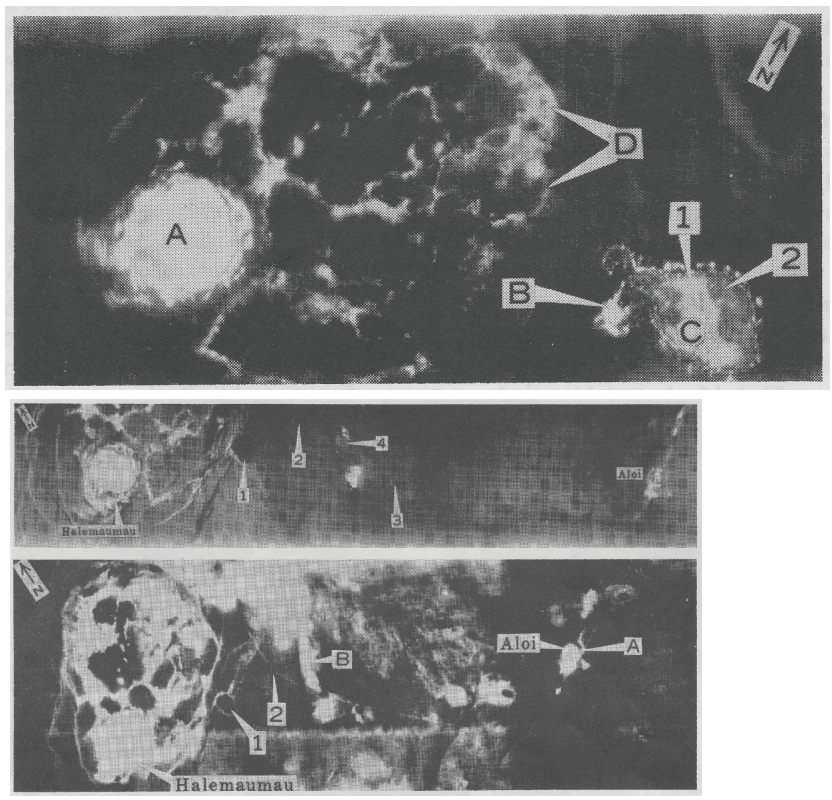

D

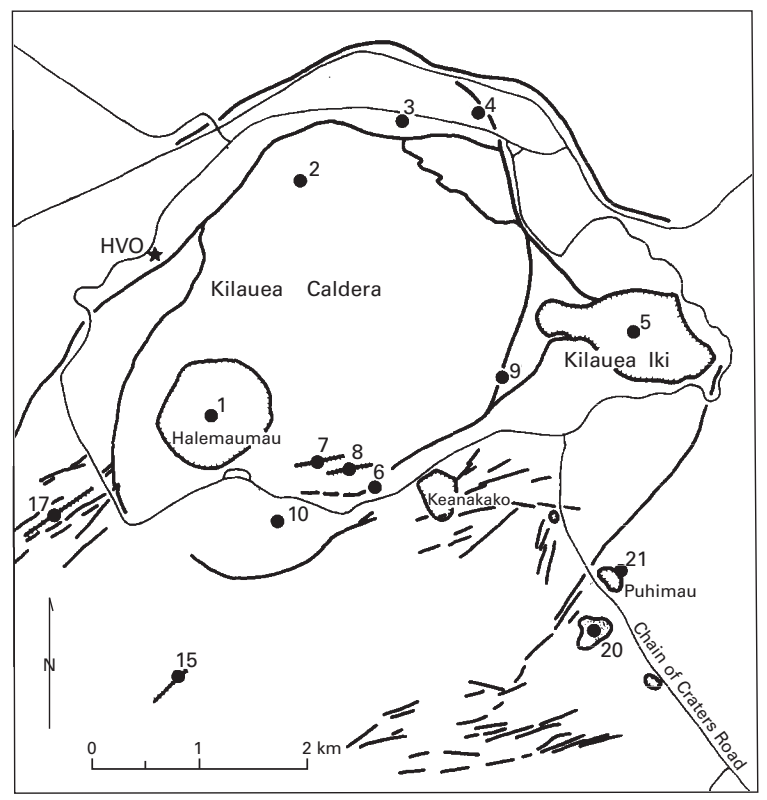

Figure 2. Maps and images from earlier studies of thermal features at Killauea's summit. $A$, Map of alteration and deposition on the floor of Killauea's caldera, from Macdonald (1955). B, Map of now-buried scarps and a debris ridge in the caldera dating to the 1800s, also from Macdonald (1955). C, Infrared images studied by Fischer and others (1964). Top image shows Kilauea's caldera and Kilauea Iki (labeled C). Middle image shows Kilauea's caldera and the upper east rift zone, extending to 'Ālo'i crater (now buried). Puhimau thermal area is the hotspot in the center of the image. Bottom image also shows Kilauea's caldera and part of the upper east rift zone, but at larger scale. D, Map of thermal areas at Kilauea's summit studied by Casadevall and Hazlett (1983). 
Mauna Loa and Hualālai. The Fischer and others (1964) survey of the floor of Kïlauea's caldera showed areas of elevated surface temperatures that had many similarities to Macdonald's (1955) map (fig. 2C), including two anomalous patches extending north of Halema' uma' $u$ into the north portion of the caldera. Casadevall and Hazlett (1983) found fumarole temperatures in the summit caldera area as high as $150^{\circ} \mathrm{C}$, and they also reported an area of high temperatures in the north portion of the caldera (fig. 2D). Fischer and others (1964) showed areas of elevated temperature on the floor of Killauea Iki Crater and on Pu'u Pua ' $i$ cone, both related to the 1959 eruption (fig. 2C).

On Mauna Loa, Casadevall and Hazlett (1983) reported several thermal areas in the summit caldera, Moku-'âweoweo, and along the upper rift zones. The hottest of these ranged from 120 to $362^{\circ} \mathrm{C}$ and were situated along the 1975 eruptive fissure on the floor of the caldera just west of its center; this area has since been buried by the 1984 flow. Sulphur Cone is an area of active sulfur gas emission, elongate down the southwest rift zone at an elevation of $3,400-3,550 \mathrm{~m}$, with temperatures of $88-90^{\circ} \mathrm{C}$ reported by Casadevall and Hazlett (1983).

Other volcanoes in Hawai' $i$ that erupted in the Holocene include Hualālai (most recent eruption in 1801; Kauahikaua and others, 2002), Mauna Kea (most recent eruption approximately 4000 years ago; Wolfe and others, 1997), and Haleakalā (last eruption dated to 1420-1620 C.E.; Sherrod and others, 2006). Fischer and others (1964) noted that no thermal anomalies were observed during aerial infrared surveys of Hualālai and the south flank of Haleakalā. No thermal surveys have been conducted on Mauna Kea, and there is no record of thermal features on that volcano as far as we know.

\section{Methodology}

The methodology in our study can be summarized as follows:

1. Download cloud-free ASTER surface kinetic temperature images (AST08) for the given location (for example, volcano's summit).

2. Manually coregister images using ENVI remote sensing software (marketed by ITT Visual Information Systems).

3. Create "Layer Stack" GeoTIFF of individual images in ENVI to make a single file with common reference frame.

4. Analyze Layer Stack GeoTIFF image in Matlab (marketed by The Mathworks, Inc.) to create (a) an average (that is, stacked) temperature image and (b) temperature time-series for particular areas of interest.

\section{Step 1: Download ASTER Data}

ASTER data were searched and ordered from the NASAUSGS WIST (Warehouse Inventory Search Tool) Web site (https://wist.echo.nasa.gov/api/). We searched for "ASTER L1A Reconstructed Unprocessed Instrument Data" over each volcano's summit area for the period 2000-2010. We chose nighttime scenes in order to minimize the effects of solar heating of the ground surface. The nighttime pass over Hawai ${ }^{i} \mathrm{i}$ is at approximately 10 p.m., and thus all of the images shown here were acquired at that time. Although an acquisition just before dawn would be the ideal time to minimize solar heating, our only choice was this 10 p.m. dataset.

Once the satellite images (granules) were found, we went through the list and examined the browse images. If the summit area was completely cloud-free in an image, we chose that image for downloading. The final step is choosing the AST08 Surface Kinetic Temperature product.

\section{Step 2: Manually Coregister Images}

ASTER images come nominally georegistered, but precise coregistration is needed for effective stacking. Therefore, we manually coregistered the images; this was the most time-consuming part of the study. Of the downloaded images for each volcano, a single reference image was chosen as the coregistration base image. The reference image was chosen on the basis of its high degree of contrast and feature definition, which would make it easy to match features with a large number of other images.

The rest of the images were then coregistered with this reference image using ENVI software (version 4.7). Typically, 10 to 15 ground control points were chosen for the coregistering to cover as much of the area of interest (that is, summit region) as possible. For the coregistration, we used a one- or two-degree polynomial fit with nearest neighbor resampling.

\section{Step 3: Create "Layer Stack" of Images}

The individual coregistered images were then resampled into the same reference frame using the "Layer Stack" function in ENVI. This Layer Stack is a single file that includes each individual image as a separate band, or channel. We used nearest neighbor resampling to create the Layer Stack, with UTM projection and WGS84 datum. This Layer Stack was then exported as a multilayer GeoTIFF file, with each image layer being a different coregistered image. This GeoTIFF file was then easily read and analyzed by Matlab.

\section{Step 4: Import and Process Layer Stack in Matlab}

The analysis of the Layer Stack in Matlab was done with two scripts. The first imported the multilayer GeoTIFF that held the Layer Stack using the "geotiffread" function. 
Thermal Mapping of Hawaiian Volcanoes with ASTER Satellite Data

It then created an average image of the multiple layers and cropped it appropriately. This represented the "stacked" thermal image.

The second script imported the multilayer GeoTIFF that held the Layer Stack and analyzed various regions of interest through time. First, the regions of interest were designated in the image using x-y pixel coordinates (though it could be done with geographic coordinates and easily converted to $\mathrm{x}-\mathrm{y}$ pixel coordinates in the script). For instance, at Killauea, several regions of interest included Halema'uma' $u$, the north caldera region, and the Puhimau thermal area. Second, a loop went through each layer in the Layer Stack, with each layer representing an individual image and specific time. At each iteration (that is, for each image and associated time), the script calculated the maximum temperature within the regions of interest. Finally, the script output a time series for each region of interest showing the maximum temperature.

\section{Results}

\section{Kīlauea}

Thermal areas at Killauea's summit are conspicuous and shown clearly by the stacked temperature map in figure 3 , which comprises 42 images. Within the summit caldera, they include a large warm area corresponding with Halema'uma'u Crater, as well as numerous areas on the caldera floor. Some of these warm areas are arcuate and linear and appear to form a continuous broad circle. Outside of the caldera floor, thermal areas are found at Kỉlauea Iki Crater and the Puhimau Crater and thermal area (figs. 4, 5).

Specific thermal areas are detailed as follows (fig. 4):

K1. Steaming Bluff.-An approximately $4 \times 4$ pixel thermal anomaly corresponds with the warm and actively steaming area at Steaming Bluff. The maximum pixelintegrated temperature is $14.8^{\circ} \mathrm{C}$, which is only slightly elevated above surrounding areas $\left(13^{\circ} \mathrm{C}\right)$.

K2. Sulphur Banks.-Another relatively small thermal anomaly is found here, where there is an area of active fumaroles. The pixel-integrated temperature is $15.2^{\circ} \mathrm{C}$, with the surrounding area at $13^{\circ} \mathrm{C}$.

K3. Rain Catchment Pond.-A very faint and small, but real, thermal anomaly corresponds with this $200 \times 100$ $\mathrm{m}$ pond. The water is probably not heated significantly from below; the higher temperature it exhibits is most likely due to a difference in thermal inertia with the surrounding rainforest.

K4. North Caldera Hotspot.- - This is the largest and hottest thermal area in Kîlauea caldera (excluding Halema'uma'u), with the highest temperatures focused on a triangular area approximately $500 \mathrm{~m}$ wide. Pixel-integrated temperatures are as high as $23^{\circ} \mathrm{C}$, almost $10^{\circ} \mathrm{C}$ above adjacent cooler portions of the caldera floor. The warm area extends up and around the north margin of the caldera floor. The entirety of this hotspot is on 1919 lava flows, which spilled out north from the Halema'uma'u lava lake (Neal and Lockwood,
2003). Numerous inflation caves in this area contain air temperatures above $60^{\circ} \mathrm{C}$ (D. Swanson, written commun., 2011).

K5. N-S Hotspot East of Postal Rift.-This linear thermal area, also entirely on the 1919 flows, is approximately $200 \mathrm{~m}$ wide and extends $1 \mathrm{~km}$ from the north rim of Halema 'uma' $u$ Crater to join with the north caldera hotspot (K4). It is approximately $300 \mathrm{~m}$ east of the Postal Rift, a notable area of activity in the early 1900s (Jaggar, 1919), but does not include the rift itself. It has relatively high temperatures (peak pixelintegrated temperature of $20.9^{\circ} \mathrm{C}$, with adjacent cool areas at $\left.13.8^{\circ} \mathrm{C}\right)$.

K6. East Caldera Linear Hotspot.-This linear hotspot, situated on the July 1974 flow, extends approximately $1.3 \mathrm{~km}$ in a north-south direction near the east margin of the caldera floor. Pixel-integrated temperatures (peak value of $17.5^{\circ} \mathrm{C}$ ) are lower than those at the north caldera hotspot (K4).

K7. Killauea Iki Hotspot.-This warm area includes most of the floor of Kilauea Iki Crater, which is the surface of the 1959 lava lake (Richter and others, 1970), estimated to be approximately $122 \mathrm{~m}$ deep by Helz and Thornber (1987). The highest temperature $\left(17.9^{\circ} \mathrm{C}\right)$ is in the west portion of the crater, 400-500 m east of the 1959 vent.

K8. SW Rim of Halema' 'uma ' $u$. - An area of temperatures slightly elevated above those of the surrounding pixels at Halema'uma' $u$ can be found here and corresponds to a large fumarolic area (several tens of meters across) perched on the wall of Halema'uma' $u$ in the area that the southwest rift zone intersects the crater.

K9. Halema' 'uma' $u$.-The floor, walls, and rim of Halema'uma'u exhibit pixel-integrated temperatures of generally $16-18^{\circ} \mathrm{C}$ (excluding $\mathrm{K} 8$ and $\mathrm{K} 10$ ), compared to nearby cool pixels on the caldera floor of about $13-13.5^{\circ} \mathrm{C}$.

K10. 2008 Overlook Vent.-A $3 \times 2$ pixel hotspot is situated at the site of the Overlook vent, which opened on March 19, 2008, immediately below the Halema'uma'u Overlook. The vent was originally $40 \mathrm{~m}$ wide and had expanded to $130 \mathrm{~m}$ by the end of 2010 . Approximately 150 $200 \mathrm{~m}$ below the vent rim, a lava lake has been sporadically present. The peak pixel-integrated temperature in the stack is $21.5^{\circ} \mathrm{C}$, but individual images have temperatures as high as $85^{\circ} \mathrm{C}$, making it the hottest thermal anomaly in this study outside of the active flow field on the east rift zone.

K11. 1974 Fissures + Southeast Sulphur Bank.-This faint anomaly, approximately $600 \mathrm{~m}$ wide and elongate in an east-west direction, corresponds with the site of the 1974 fissures as well as the area known as Southeast Sulphur Bank (or South Sulphur Bank), an area of active fumaroles that has been active for at least 180 years.

K12. North of Southeast Sulphur Bank.-This area of elevated temperatures does not correspond with any notable surface features and extends across several flows of dramatically different ages (1882-1974; Neal and Lockwood, 2003), but it exhibits pixel-integrated temperatures as high as $17.7^{\circ} \mathrm{C}, 3^{\circ} \mathrm{C}$ higher than those of the 1974 fissures and Southeast Sulphur Bank to its immediate south. 

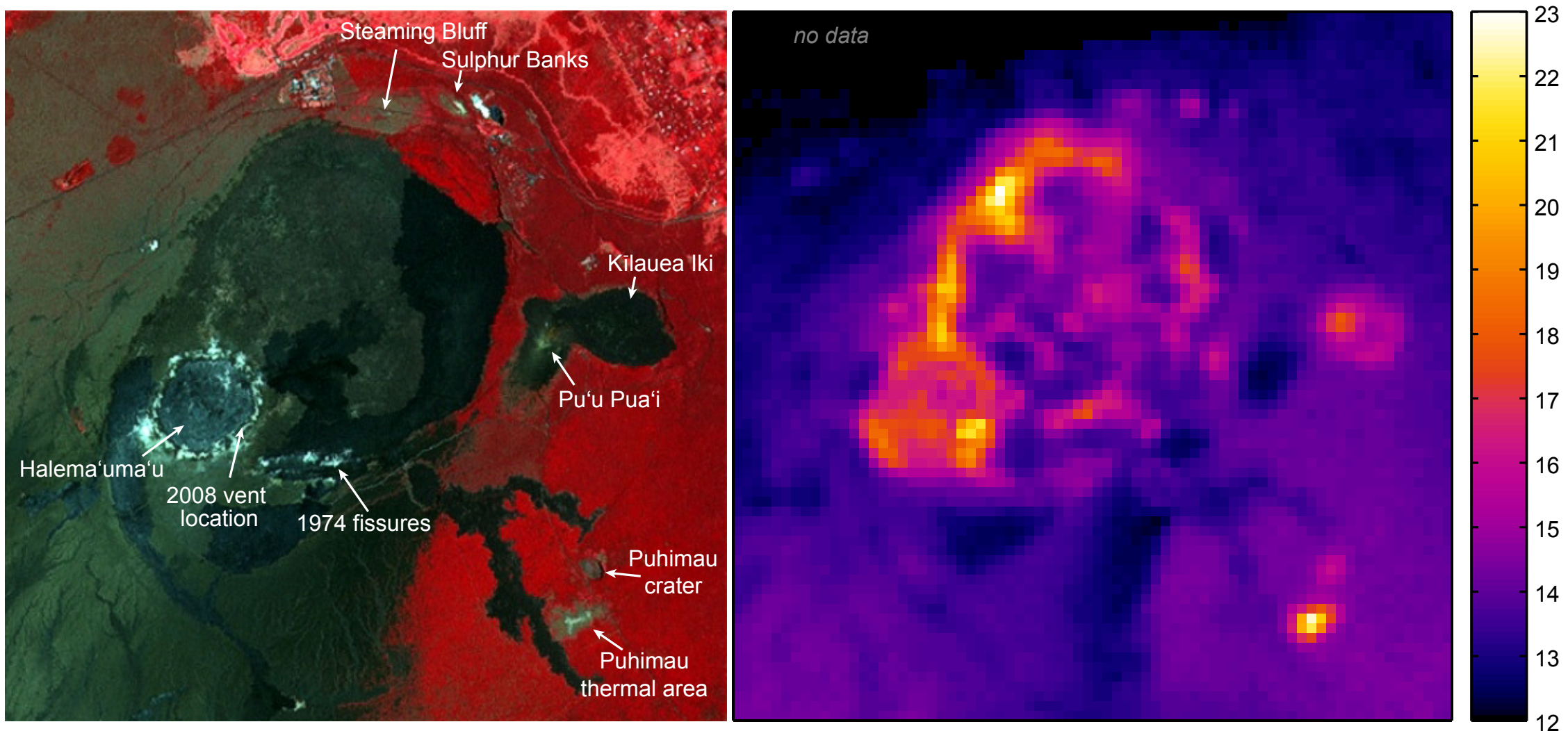

0

$1 \mathrm{~km}$

Figure 3. ASTER VNIR (visible and near-infrared) image (left) and surface kinetic temperature map (right) of Kïlauea's caldera. The VNIR image was taken on May 4, 2000, before the opening of the vent in Halema'uma'u in 2008. The thermal map is an average of 42 individual ASTER surface kinetic temperature images collected between 2000 and 2010. 
Temperature $\left({ }^{\circ} \mathrm{C}\right)$

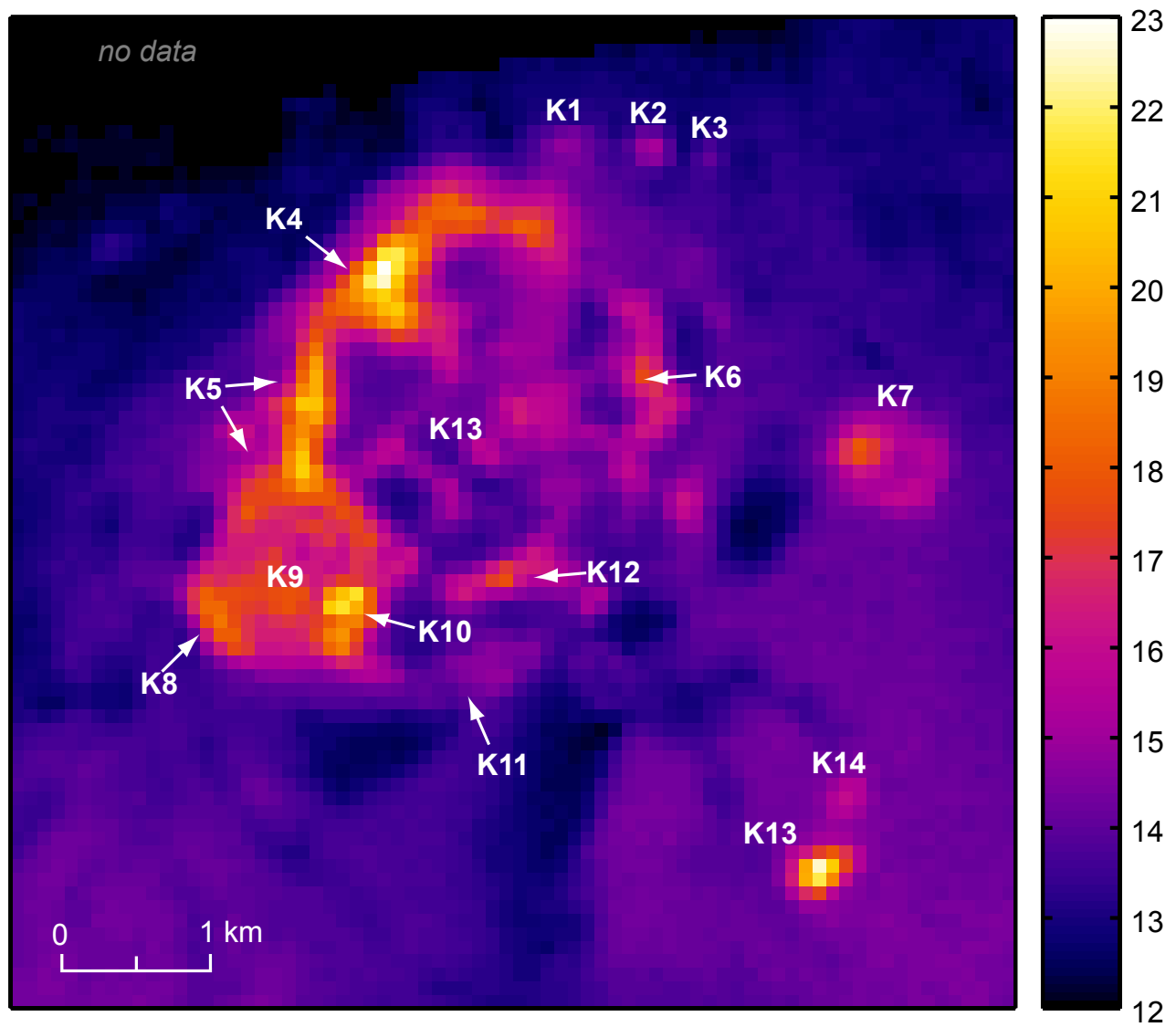

Figure 4. Surface kinetic temperature map of Kilauea's summit area, identical to that shown in figure 3, with thermal areas labeled (see text).

St. Dev. $\left({ }^{\circ} \mathrm{C}\right)$

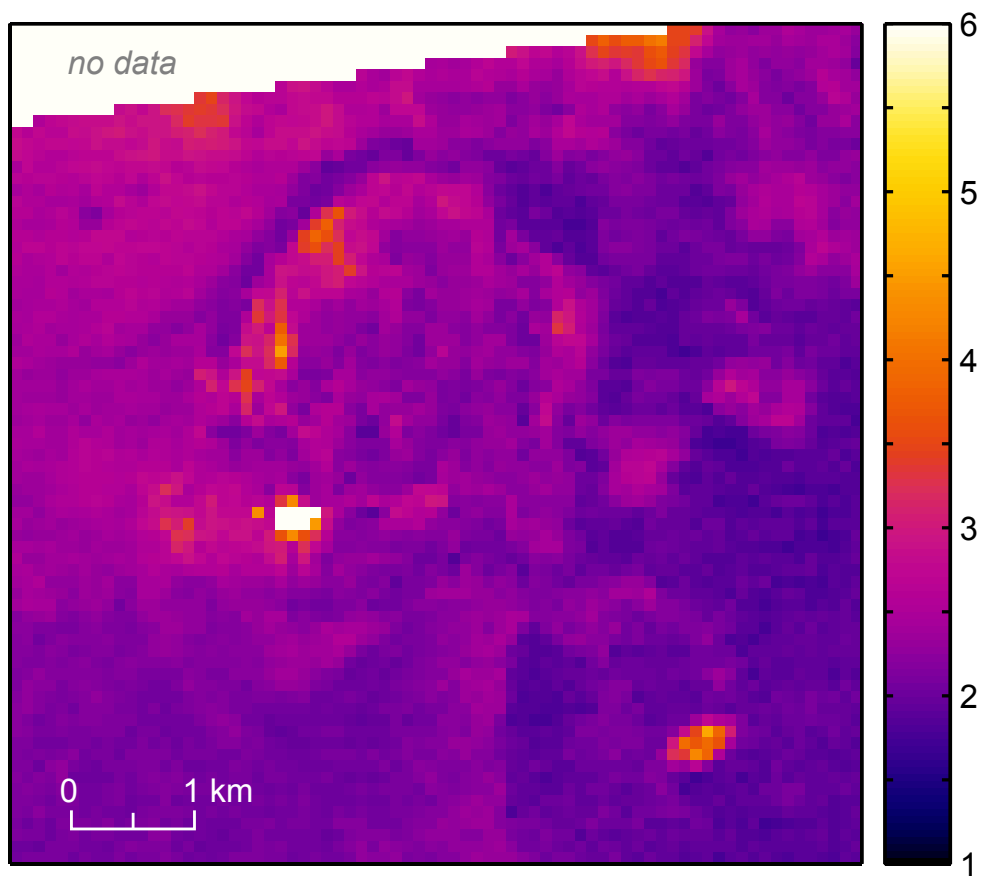

Figure 5. Standard deviation of surface temperature variation over time within the 42-image stack for Kïlauea summit. 
K13. Puhimau Thermal Area.-This hotspot is approximately $3 \times 6$ pixels, similar in size to the grassy area that defines the thermal area. As noted above, this thermal area first appeared in the middle 1930s and was probably related to a shallow intrusion. The pixel-integrated temperatures reach $22.6^{\circ} \mathrm{C}$, or about $8^{\circ} \mathrm{C}$ above those of the surrounding rainforest.

K14. Puhimau Crater.-This small and faint hotspot $\left(3 \times 3\right.$ pixels, $\sim 3^{\circ} \mathrm{C}$ above background) corresponds with a 100 -m-wide, grassy, steaming area on the northeast rim of Puhimau Crater. There is also a steaming area on the northwest side of the crater floor (D. Swanson, written commun., 2011). Puhimau means "ever smoking."

Figure 5 shows an image of the standard deviation in surface temperatures over time for each pixel, based on the stack of 42 images. This is provided to give a picture of baseline variation at the thermal areas to aid in identifying future anomalous activity. In general, thermal areas have a standard deviation of $2-5^{\circ} \mathrm{C}$, with the exception of the new vent in Halema'uma' $\mathrm{u}$, which has a standard deviation of $15^{\circ} \mathrm{C}$.

The main thermal features on the caldera floor correspond to areas of light-colored deposition and rock alteration that are clearly visible in satellite imagery and aerial photographs. Figure 6 shows these areas mapped from Google Earth, compared with the thermal map of the summit. Macdonald
(1955) first mapped the correspondence between these lightcolored areas and thermal activity, and our work shows that this relationship has been maintained over the past 50 years. As Macdonald (1955) first noted, the altered areas correspond with spots of active steaming. Macdonald (1955) described the deposition as being primarily opal, and below this crust the host rock is partly altered to clay minerals and iron oxides for thicknesses of a few millimeters to a few centimeters. He explained the silica in the opal as being transported and deposited by the rising steam, which leaches silica from the altered rocks along the walls of the crack.

Figure 7 shows the time-series results for Kilauea's summit region and tracks the maximum pixel-integrated temperature within a given region of interest through time. Except for Halema' uma' $u$, there is no visible trend to the data. Generally the peaks occur in the summer and troughs in the winter, indicating an inconsequential seasonal influence.

The Halema 'uma'u region of interest (fig. 8) is the only one showing a systematic change during the study period, with temperatures increasing to $85^{\circ} \mathrm{C}$ following the opening of the new vent on March 19, 2008. Note, however, that the April 15,2008 , image does not show an anomalous temperature, even though the vent was open and active. Examination of that image reveals that a thick gas plume masked the elevated temperatures within the vent. Temperatures after this date

Temperature $\left({ }^{\circ} \mathrm{C}\right)$

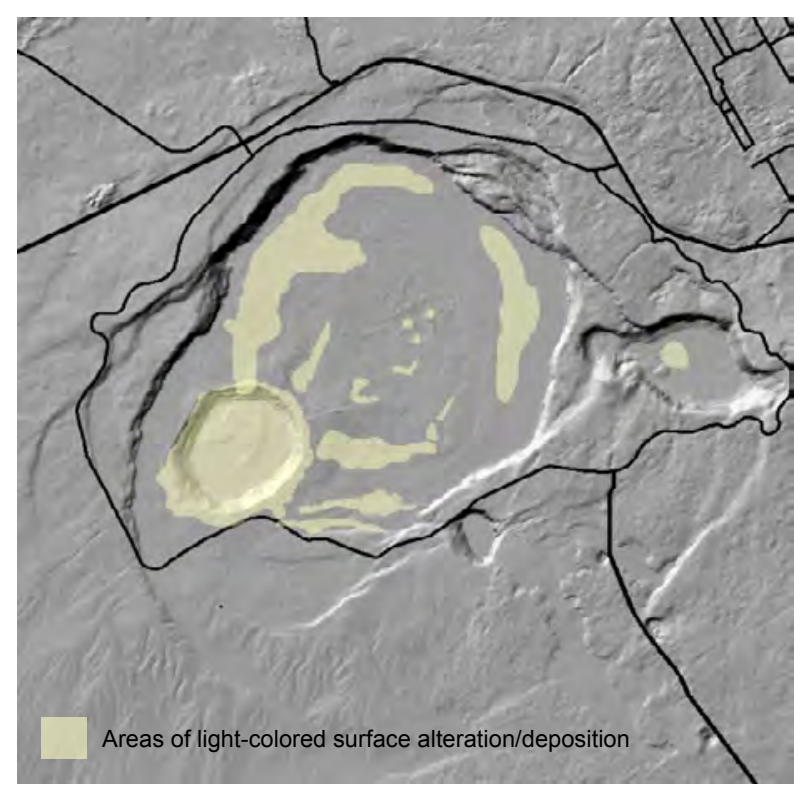

0
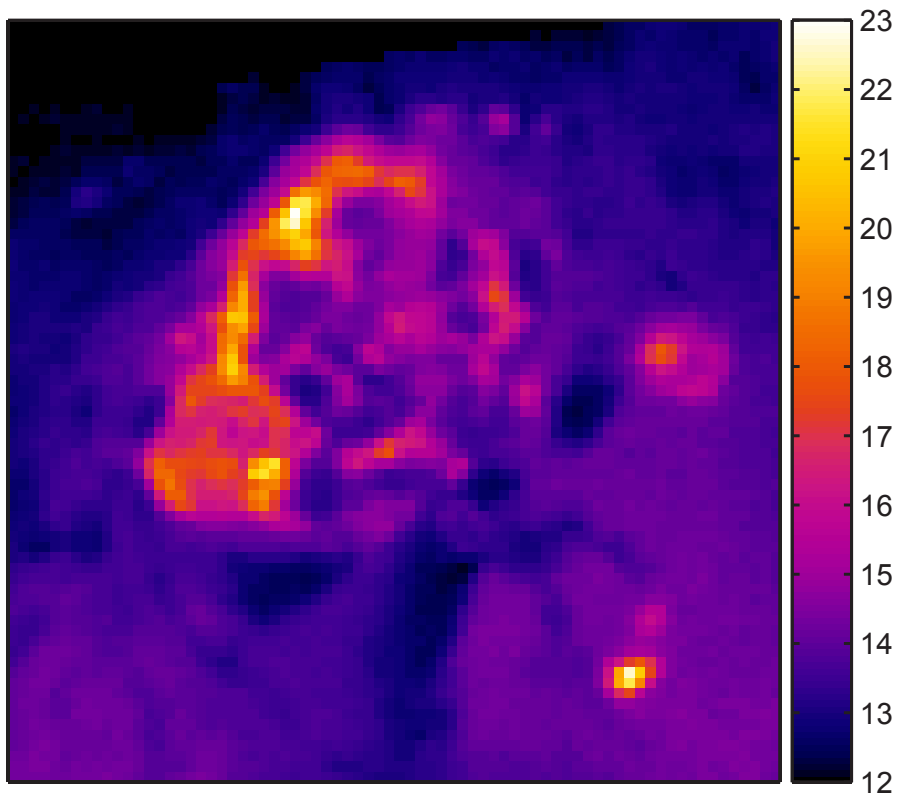

$1 \mathrm{~km}$

Figure 6. Comparison of present-day areas of alteration and deposition on the floor of Kilauea caldera with surface temperatures. Image at left is a shaded digital elevation model of the caldera and surrounding area, with areas of alteration and deposition mapped using Google Earth imagery. Black lines are roads. Image at right is the surface kinetic temperature map also shown in figures 3 and 4. 
are elevated well above the 2000-2007 background range, though highly variable. For instance, data points from very late 2008 and mid-2009 are elevated above preeruption background but are significantly lower than other coeruptive values. Examination of the images shows that the thick eruption plume was again masking the vent in these cases. This plot also shows that there was no detectable change in surface temperatures leading up to the March 2008 eruption onset, in line with ground-based surveys by a thermal camera in January and February of 2008 that showed no anomalous thermal behavior before mid-March.

Although our focus here is the summit region, a single image from November 25, 2007, is also shown to provide a broader picture of thermal areas on Kīlauea (fig. 9). From this image, several additional distinct thermal areas can be identified:
K15. North of Cone Crater.-This 700-m-long anomaly is about $650 \mathrm{~m}$ north of Cone Crater. Pixel-integrated temperatures are about $5^{\circ} \mathrm{C}$ above the surroundings, and the thermal area appears to cover the lowermost December 1974 fissures (fissures H and I of Lockwood and others, 1999), as well as an area of alteration off of the 1974 flow, immediately south of fissure $\mathrm{H}$. The area south of fissure $\mathrm{H}$ may be related to gas-emitting fissures that opened during an intrusion in this area on August 10, 1981, and an intrusion in May 1963 also produced cracks in this area (Hawaiian Volcano Observatory internal reports, August-September, 1981). There are sulfur deposits in this area, and steaming has continued to the present.

K16. Pauahi-Hi 'iaka Craters.-A very subtle northwesttrending linear anomaly extends, in two segments, $1.5 \mathrm{~km}$ from Pauahi Crater into Hi'iaka Crater.

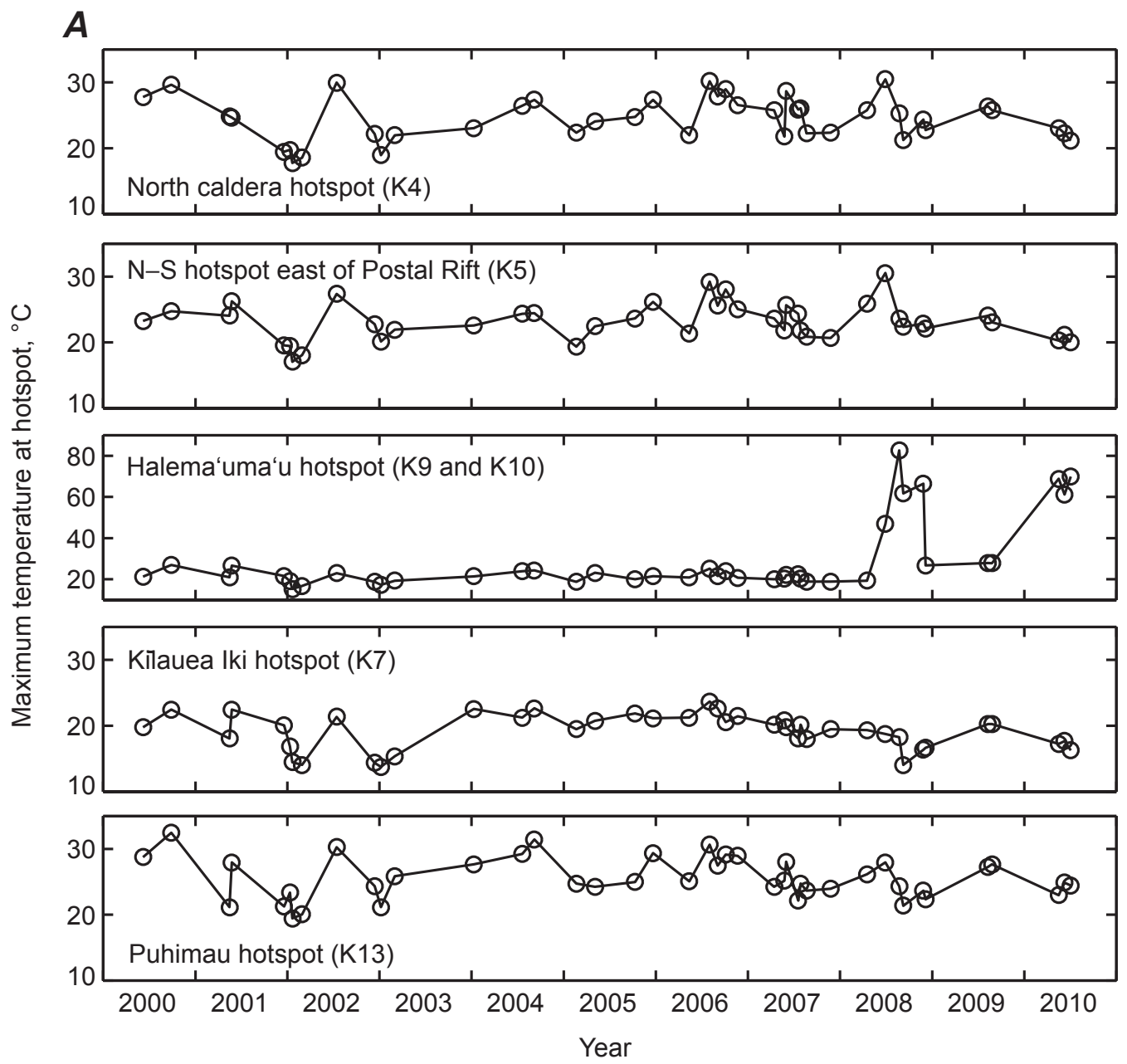

Figure 7. Changes in temperature in several regions of interest at Kilauea's summit, 2000 to 2010. $A$, Trends in maximum temperature. Note the different $y$-axis scale for Halema'uma'u. $B$, Maximum temperature relative to background temperature ( $\left.T_{\max }-T_{\mathrm{bg}}\right)$. The location for the background temperature was chosen as the 1982 lava flow in the south caldera, at coordinates 19.3948, -155.2792 (WGS84). 
K17. Mauna Ulu Summit Crater.-This $4 \times 2$ pixel anomaly is situated at the summit crater of Mauna Ulu shield (formed during the 1969-1974 eruption; Swanson and others, 1979; Tilling and others, 1987) and exhibits pixel-integrated temperatures just $2^{\circ} \mathrm{C}$ above the surroundings. Active steaming in and around the summit crater is present.

K18. East of Mauna Ulu.-Steaming cracks have been present along the rift zone between Mauna Ulu and Makaopuhi, even before the brief intrusion that occurred on June 17, 2007 (referred to as the Father's Day intrusion), which opened cracks in this area and fed a very small eruption on the north flank of Kāne Nui o Hamo shield (Poland and others, 2008). A line of segmented thermal anomalies begins about $1.8 \mathrm{~km}$ east of Mauna Ulu's summit and extends east $2.1 \mathrm{~km}$ across Kāne Nui o Hamo, with pixel-integrated temperatures elevated $4-6^{\circ} \mathrm{C}$ above the surroundings.
Numerous steaming cracks are presently found in this area.

K19. West Wall of Makaopuhi Crater.-A 900-m-long thermal anomaly, with pixel-integrated temperatures as much as $4^{\circ} \mathrm{C}$ above the surroundings, is in the west portion of Makaopuhi Crater and appears to cut the west rim. Steaming sources can be seen perched on the west crater wall today.

The November 25, 2007, temperature image (fig. 9) also shows the active flow field on the east rift zone. The highest temperature areas are east of the D-vent, which opened 2.5 $\mathrm{km}$ east of $\mathrm{Pu}^{\prime} \mathrm{u}{ }^{\prime} \overline{\mathrm{O}}^{`} \overline{\mathrm{o}}$ on July 21, 2007, and represent the Episode 58 flows that were active and/or recently active at the time of the image. Black areas near the vent are sensorsaturated pixels and correspond well with areas known to be active (that is, fluid and mobile) at the time of the image. A line of saturated pixels extends northeast, representing a large perched lava channel (Patrick and others, 2011), as well as

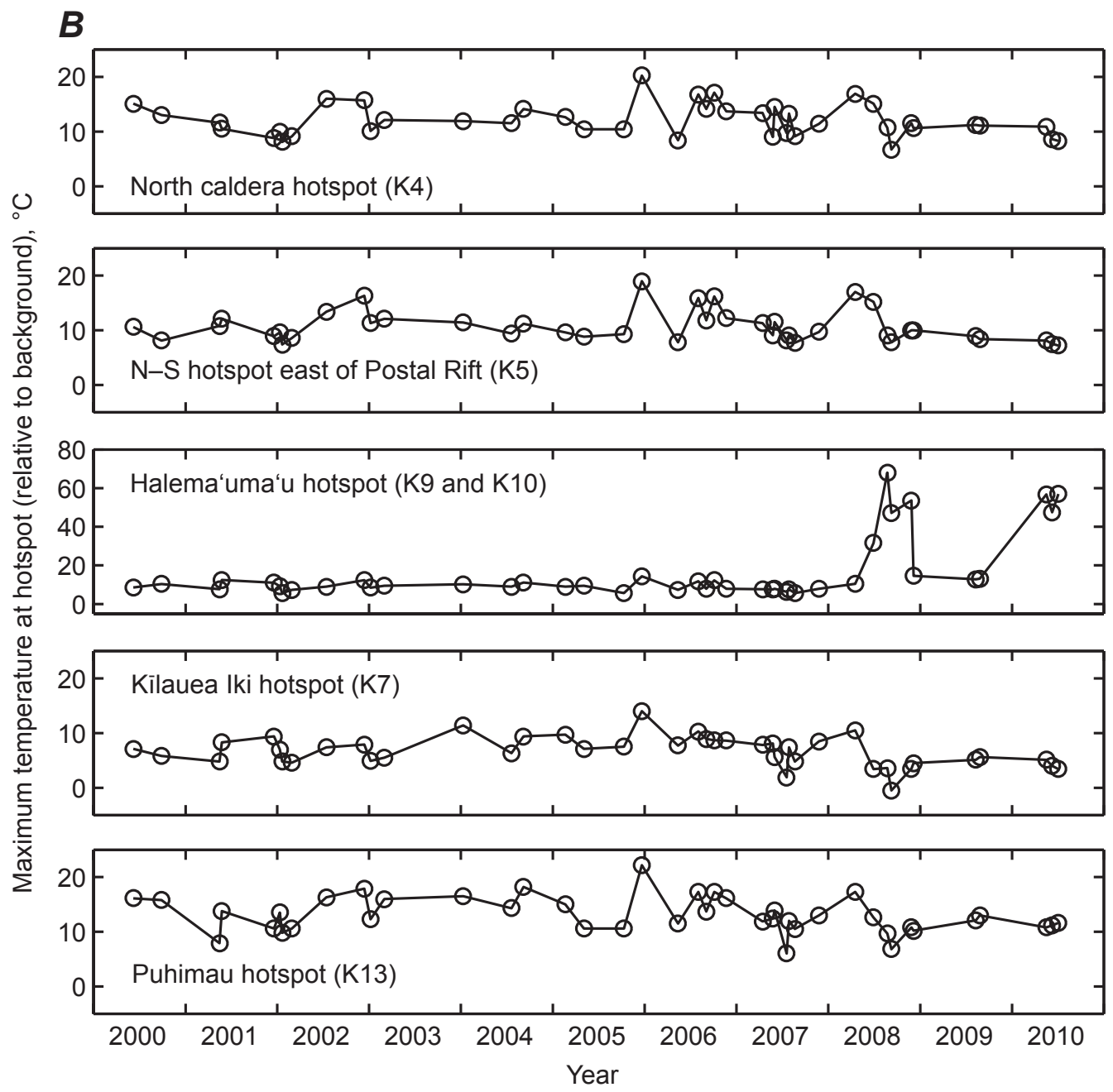

Figure 7.-Continued 


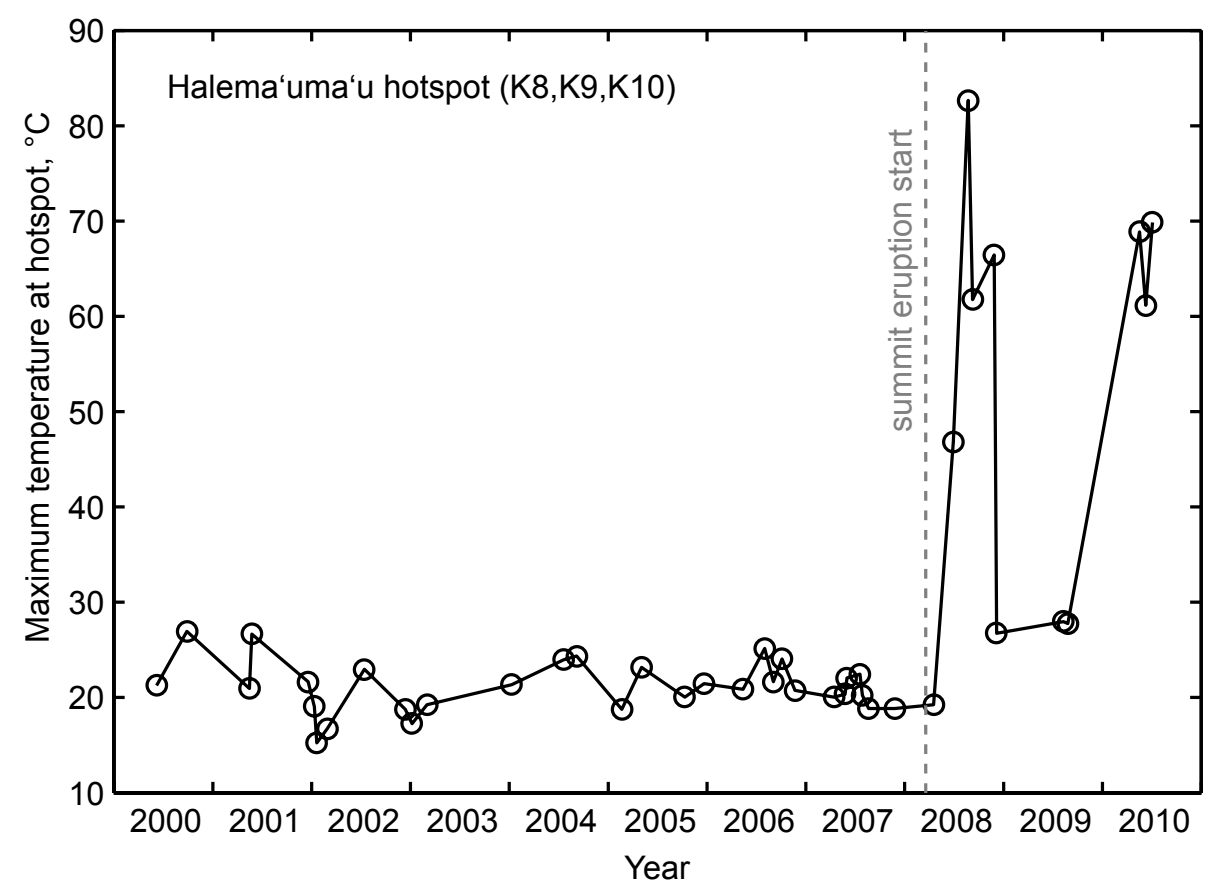

Figure 8. Trend of maximum temperature at the Halema'uma'u region of interest, 2000 to 2010. The abrupt increase in temperatures in 2008 resulted from the new vent that opened on March 19, 2008.
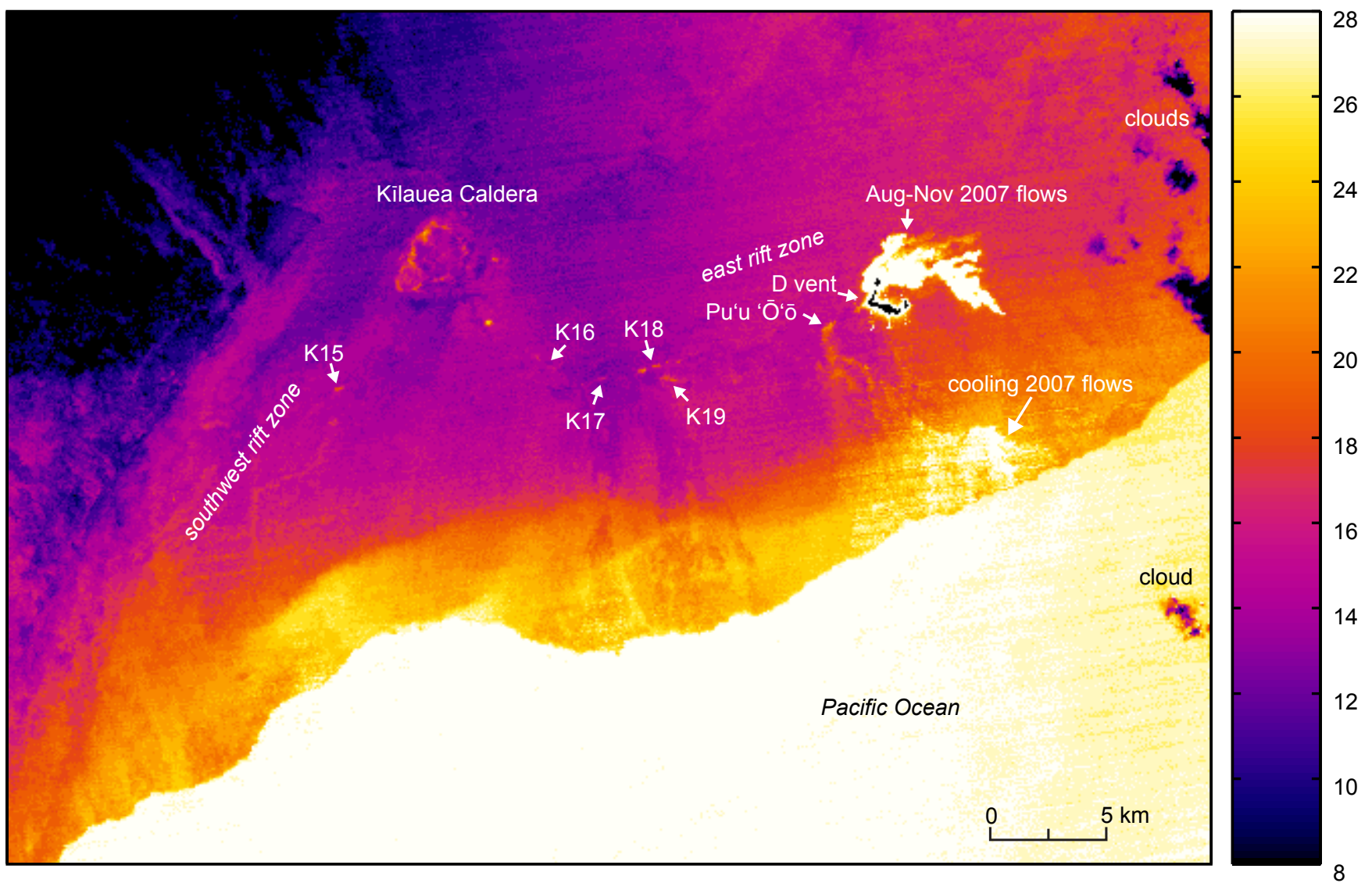

Figure 9. Single ASTER surface kinetic temperature image of much of Kïlauea Volcano on November 25, 2007, showing additional thermal areas outside the summit region. 
southeast, representing the Thanksgiving Eve Breakout flows (Patrick and Orr, 2011). $\mathrm{Pu}^{\prime} \mathrm{u}^{\prime} \mathrm{O}^{`}{ }^{\circ}$, the center of much of the ongoing east rift zone eruption, is shown by an area of warm, but not hot, temperatures; the crater did not host active lava at that time but was emitting large amounts of gas (Poland and others, 2008). A widening swath of elevated temperatures extends south from $\mathrm{Pu}^{\prime} \mathrm{u}$ ' $\mathrm{O}^{`} \bar{o}$ to the ocean, representing warm but inactive flows that had been recently erupted from vents at the base of $\mathrm{Pu}^{\prime} \mathrm{u}$ ' $\overline{\mathrm{O}}^{`} \overline{\mathrm{o}}$. The warm area marked on the coastal plain covers Episode 55 flows that were emplaced in early 2007.

\section{Mauna Loa}

Figures 10 and 11 show the stacked temperature map for the Mauna Loa summit region, which comprises 64 images. The image is dominated by a clear temperature decrease with elevation that is due to the atmospheric lapse rate (summit elevation is $4,170 \mathrm{~m}$ ). Several features stand out from this background temperature trend, including several hotspots in the summit caldera, Moku'āweoweo, and along the southwest rift zone. Specific thermal areas are detailed as follows (fig. 12):
M1. West Caldera Floor, Below Summit.-This $3 \times$ 3 pixel thermal anomaly, approximately $600 \mathrm{~m}$ west of the 1975 fissure in the western portion of the caldera, has a pixel-integrated temperature of $3.4^{\circ} \mathrm{C}$, about $8^{\circ} \mathrm{C}$ above the cool portions of the caldera floor. This feature has the highest pixel-integrated temperature in the summit caldera. The hotspot is entirely on 1984 flows and corresponds with a 230-m-diameter circular area of whitish alteration and deposition that resembles the altered regions on the floor of Killauea caldera described above. The area coincides with a distinct snow-free patch in the winter (fig. 11). Although in the same general area, this feature is not the same as the spot described by Casadevall and Hazlett (1983) on the western wall of Moku'āweoweo caldera (their spot ML-6, Oasis steam vent), because that spot was situated on the wall itself whereas M1 is limited to the caldera floor. A faint line of elevated temperatures appears to connect this hotspot with the 1975 fissure hotspot (M2) described below.

M2.1975 Fissure.-This $2 \times 3$ pixel anomaly is nearly as warm (at $3.4^{\circ} \mathrm{C}$ ) as the west caldera floor hotspot M1 and is directly above the 1975 eruptive fissure (Lockwood and others, 1987) buried by 1984 flows on the floor of Moku'āweoweo. This hotspot also corresponds with a 70-m-wide

Temperature $\left({ }^{\circ} \mathrm{C}\right)$

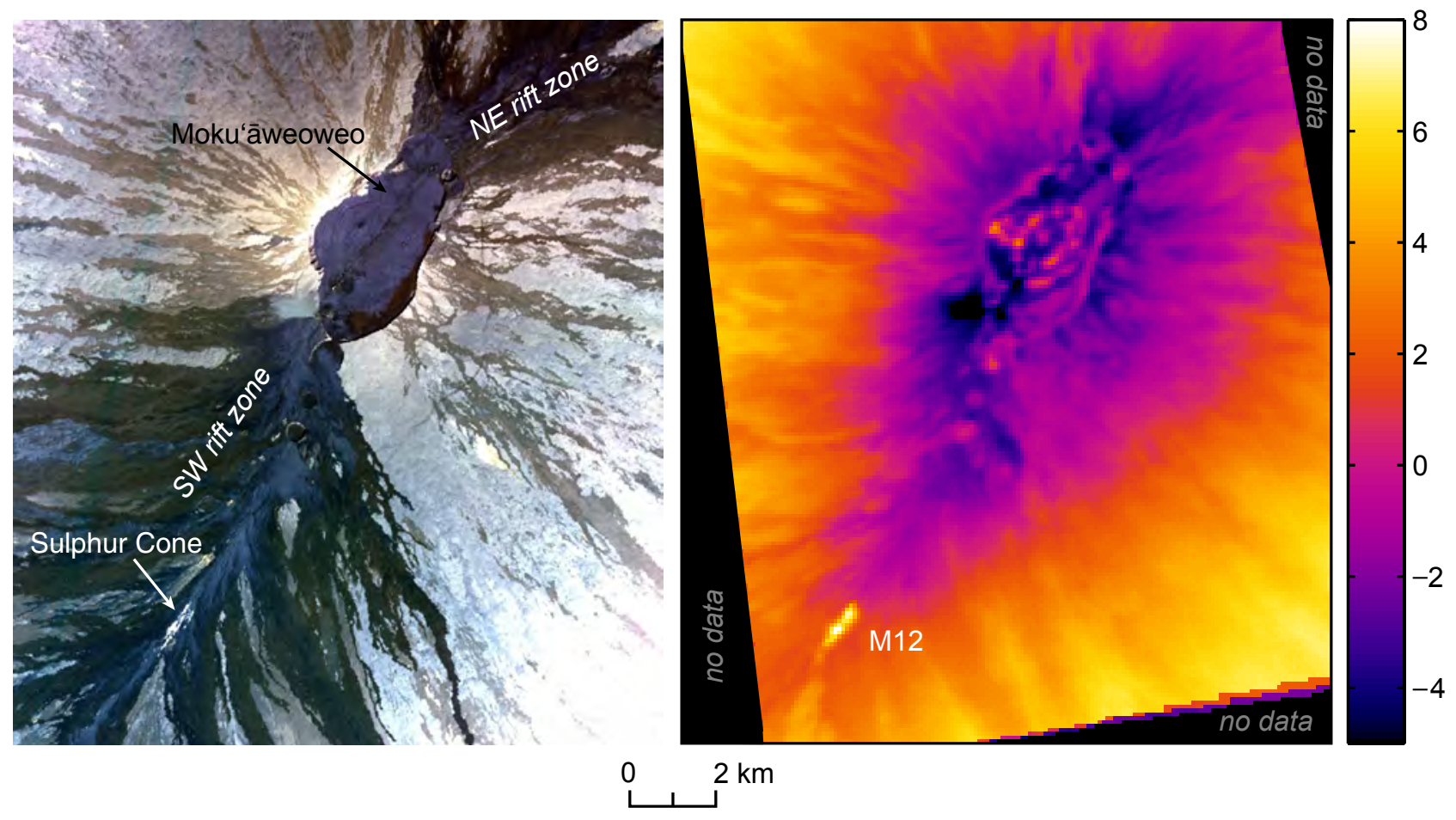

Figure 10. ASTER VNIR image (left) and surface kinetic temperature map (right) of Mauna Loa's summit caldera (Moku'āweoweo) and upper rift zones. The VNIR image was taken on February 6, 2003. The thermal map is an average of 64 individual ASTER surface kinetic temperature images collected between 2000 and 2010. One thermal area (M12) is noted in this figure, and others are shown in figure 12. 

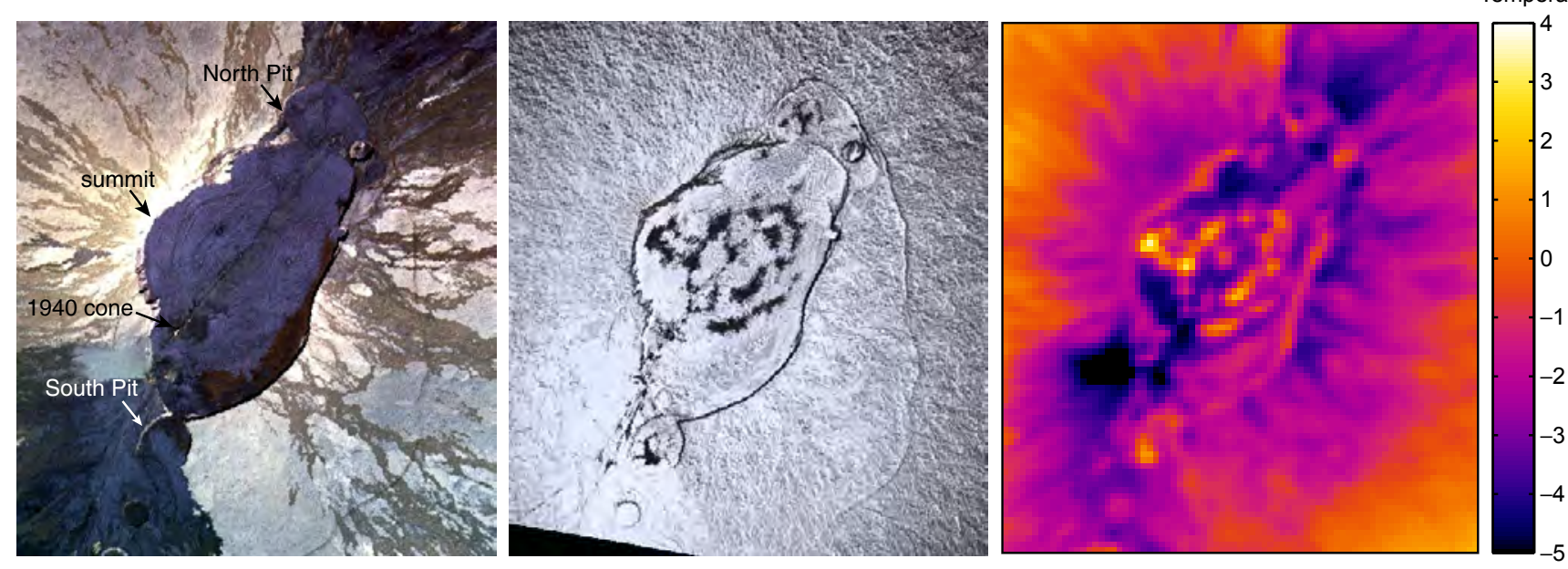

0

$2 \mathrm{~km}$

Figure 11. Close-up views of Mauna Loa summit, all at same scale. Left: ASTER VNIR image acquired on February 6, 2003, showing typical conditions. Middle: ASTER VNIR image from February 18, 2005, showing snow cover at the summit, which reveals snow-free areas indicative of active thermal areas. Right: Enlarged part of the ASTER temperature map shown in figure 10.

area of alteration and deposition. High-temperature fumaroles (as hot as $350^{\circ} \mathrm{C}$ ) and intense fuming were present in this area between the 1975 and 1984 eruptions (see figure 19.17 in Lockwood and others, 1987), with visible fuming ceasing after the area was covered by flows from the 1984 eruption. Figure 11 shows that this area corresponds with a snow-free patch in the winter.

M3. 1975 Fissure, North Portion of Caldera.-Another thermal anomaly, on 1984 flows 260 m northeast of M2 and over the buried 1975 fissure, is clearly connected to M2 by a line of elevated temperatures corresponding to the trace of the 1975 fissure. This thermal anomaly again corresponds with a small area of alteration and deposition, as well as a snow-free patch (fig. 11).

M4. Caldera Center.-This small thermal anomaly, close to the central point of the caldera, does not fall on any linear thermal feature like many of the other thermal anomalies in the caldera. It is, however, situated on the 1984 fissure (Lockwood and others, 1987) and corresponds with a very small $(15 \times 30 \mathrm{~m})$ but conspicuous area of alteration and deposition, as well as a snow-free patch (fig. 11).

M5. North Pit.-This is a relatively faint thermal anomaly, about $4 \times 4$ pixels in size, and is confirmed by the snow-free patch in this area shown in figure 11.

M6. Lua Poholo.-This thermal anomaly is distinct, with a pixel-integrated temperature of $-0.2^{\circ} \mathrm{C}$, or about $4^{\circ} \mathrm{C}$ above the surroundings, but the crater is covered in snow during the winter (fig. 11), and therefore it may not be a genuine thermal area.

M7, M8, M9. Linear Thermal Anomaly East of Caldera Center.-This linear, arcuate thermal anomaly is $1.5 \mathrm{~km}$ long and mirrors the linear anomaly comprising M2 and M3. The highest pixel-integrated temperature occurs at the south end (M9), in line with M1 and M2. The area is snow free in the winter (fig. 11).

M10. East Caldera Arcuate Linear Hotspots.-A long northeast-trending arcuate linear hotspot is situated immediately south of the M7-M9 line, with the highest pixel-

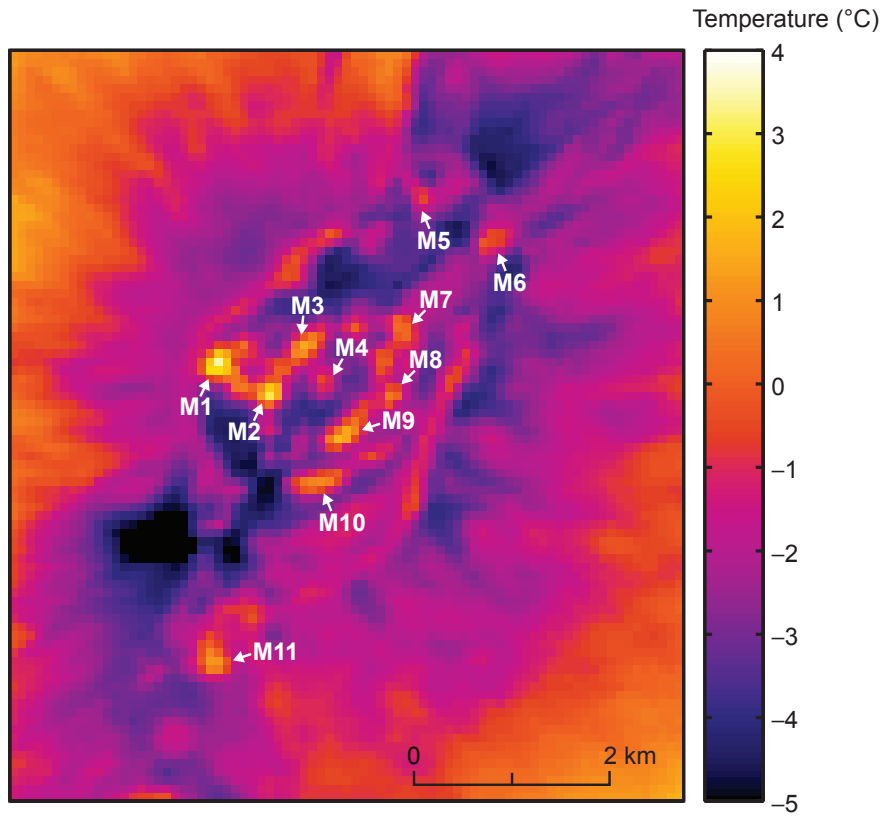

Figure 12. Enlargement of temperature map of Mauna Loa shown in figure 11, with thermal areas labeled. Thermal area M12 is outside the image but is shown in figure 10. 
integrated temperatures at the south end of the anomaly. The area is snow free in the winter (fig. 11).

M11. South Pit. - A conspicuous $2 \times 3$ pixel thermal anomaly, centered in the south portion of South Pit, has a pixel-integrated temperature of $1.2^{\circ} \mathrm{C}$, as much as $4.5^{\circ} \mathrm{C}$ above the surroundings. The area is snow free in the winter (fig. 11).

M12. Sulphur Cone.-This, the largest thermal anomaly on Mauna Loa, is approximately $1.3 \mathrm{~km}$ long by $0.3 \mathrm{~km}$ wide (fig. 10). Pixel-integrated temperatures are as high as $8.5^{\circ} \mathrm{C}$ (that is, $\sim 7^{\circ} \mathrm{C}$ above the surroundings), the highest of any thermal anomaly on Mauna Loa, and most of the anomaly contains temperatures $>5^{\circ} \mathrm{C}$. It is conspicuous in both the thermal infrared and visible wavelengths, appearing as a bright whiteyellow area amid black lava flows. The area contains abundant sulfur deposits and steam vents, and a preserved sulfur flow reactivated during the 1950 eruption (Skinner, 1970).

Figure 13 shows an image of the standard deviation in surface temperatures for each pixel, based on the stack of 64 images. In general, thermal areas on Mauna Loa have a standard deviation of $3-4^{\circ} \mathrm{C}$, but Sulphur Cone is as high as $5^{\circ} \mathrm{C}$.

Figure 11 (middle) shows an ASTER visible image (15-m pixel size) acquired on February 18, 2005, when there was thick snow cover at the summit. The snow-free areas help reveal additional thermal areas that are too small (and/ or at too low a temperature) to be conspicuous in the thermal maps. Most notable is the line of small, discontinuous snowfree patches that delineate the 1975 and 1984 fissures. The 1984 fissure extends from the center of the caldera, near

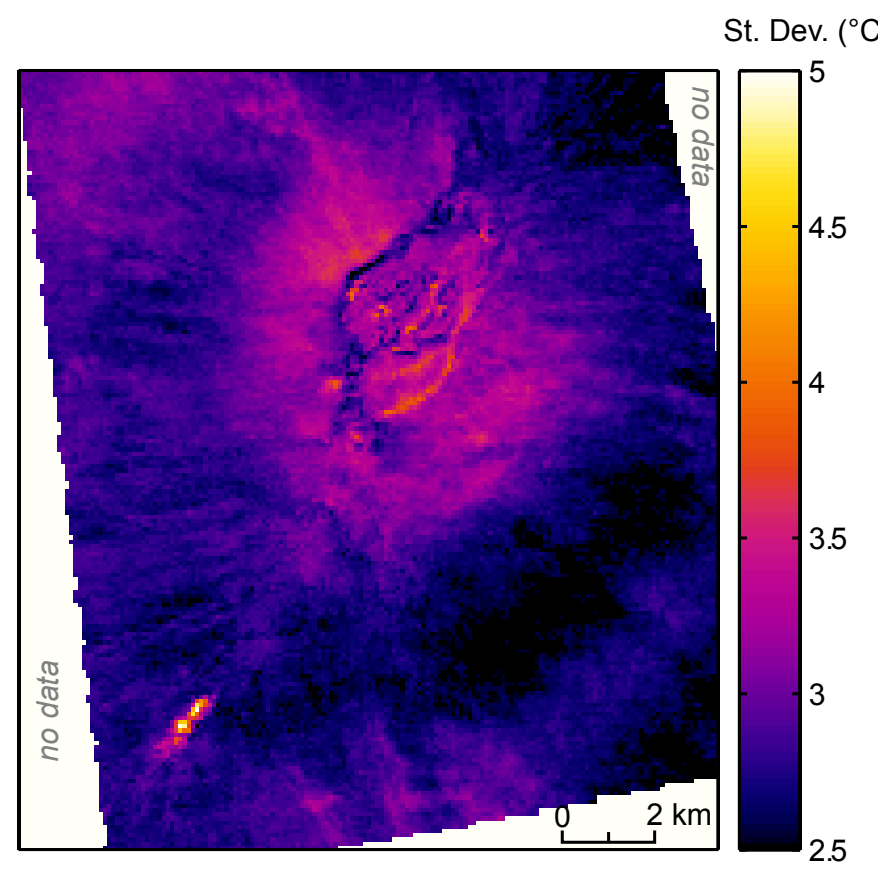

Figure 13. Standard deviation of surface temperature variation over time within the 64-image ASTER stack for Mauna Loa.
M4, through the 1940 cone and past the south rim of the caldera just west of South Pit. The 1975 fissure also passed through the 1949 cone, just south of the 1940 cone, and was coincident with the 1984 fissure south of this point (Lockwood and others, 1987).

Figure 14 shows the temporal trend in maximum temperatures for two regions of interest on Mauna Loa. As at Kîlauea, peaks and troughs appear to occur in summer and winter, respectively, suggesting seasonal influence. Overall, there is no systematic trend in any of the regions of interest. Most notably, there is no change in temperatures associated with the 2002-2004 inflation and earthquake swarm that implied an increase in magma supply to the summit magma chamber during that period (Miklius and Cervelli, 2003; Miklius and others, 2005; Amelung and others, 2007). The anomalously elevated relative temperature in early 2005 , shown in figure $14 B$, is simply due to an unusually low background temperature at that time; it is not anomalous in absolute temperature (fig. 14A).

\section{Hualālai}

The stacked temperature map for Hualālai (fig. 15) comprises 16 images and is dominated by a topographic temperature gradient. Several small thermal anomalies north and southeast of the summit correspond with pit craters. It is reasonable to think that pit craters can host elevated heat flow; however, we suspect that these pit-crater thermal anomalies result from the sheltered nature of the depression or from the favorable angle of the crater walls for solar heating. Nevertheless, a closer inspection of these pit craters is warranted. The warm lava flow $11 \mathrm{~km}$ southeast of the summit is prehistoric (Moore and others, 1987); it likely appears warmer than its surroundings because it was differentially heated by the sun. This could be a result of its higher emissivity (or lower albedo), or, perhaps, it simply has a different thermal inertia than the surrounding surface.

\section{Mauna Kea}

The stacked temperature map for Mauna Kea (fig. 16) comprises 21 images and is dominated by a topographic temperature gradient, with no detectable volcanic thermal anomalies. The summit area is covered with numerous cinder cones, which appear colder than their surrounding because of their elevation and, possibly, exposure.

\section{Haleakalā}

The stacked temperature map for Haleakalā (fig. 17) comprises just 8 images and is also dominated by a topographic temperature gradient with no detectable volcanic thermal anomalies. 

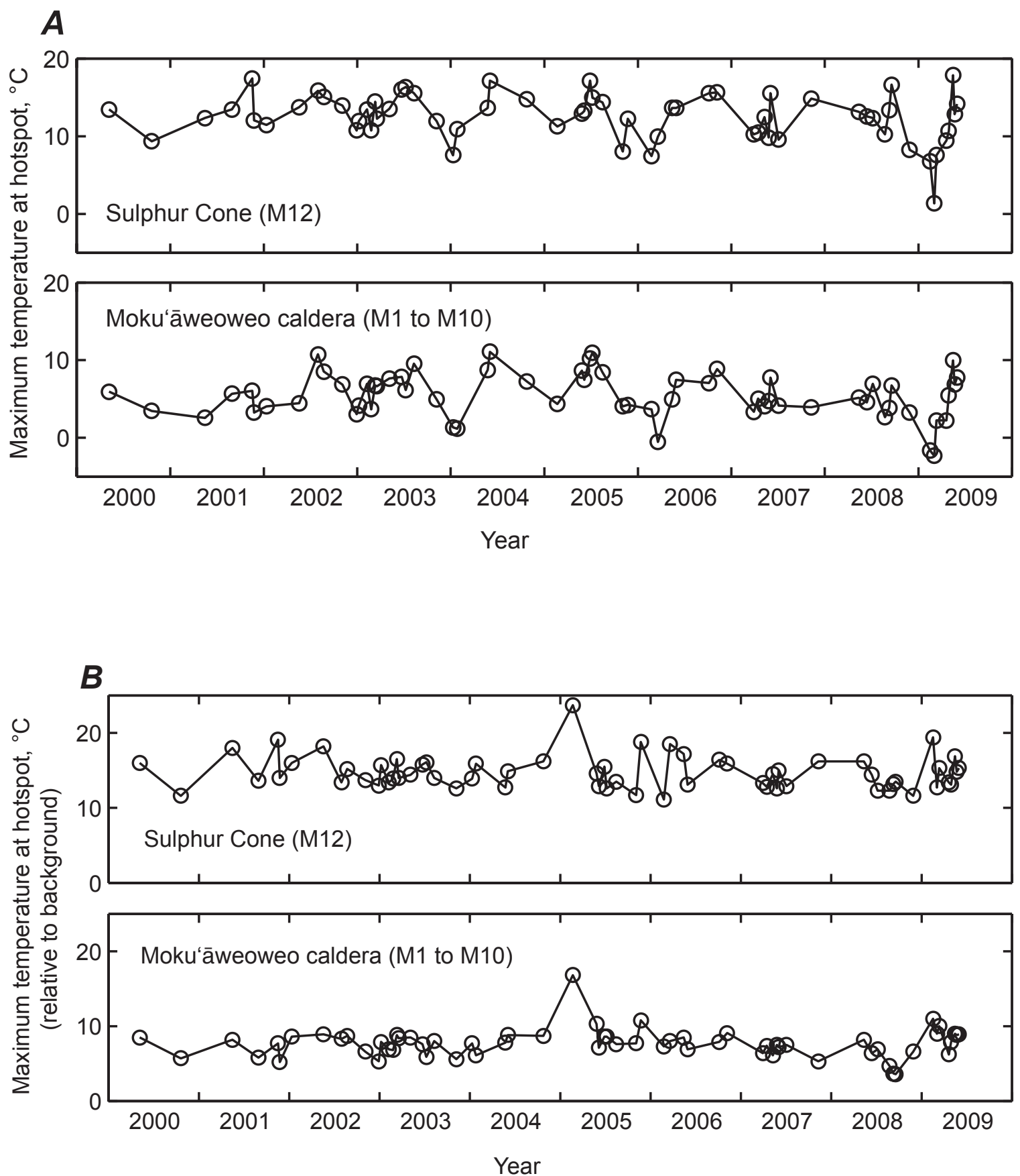

Figure 14. Changes in temperature in several regions of interest on Mauna Loa, 2000 to 2010. $A$, Trend in maximum surface temperature. $B$, Maximum temperature relative to background temperature $\left(T_{\max }-T_{\mathrm{bg}}\right)$. The location for the background temperature was chosen as the summit, at coordinates 19.4751, -155.6076 (WGS84). 
Temperature $\left({ }^{\circ} \mathrm{C}\right)$

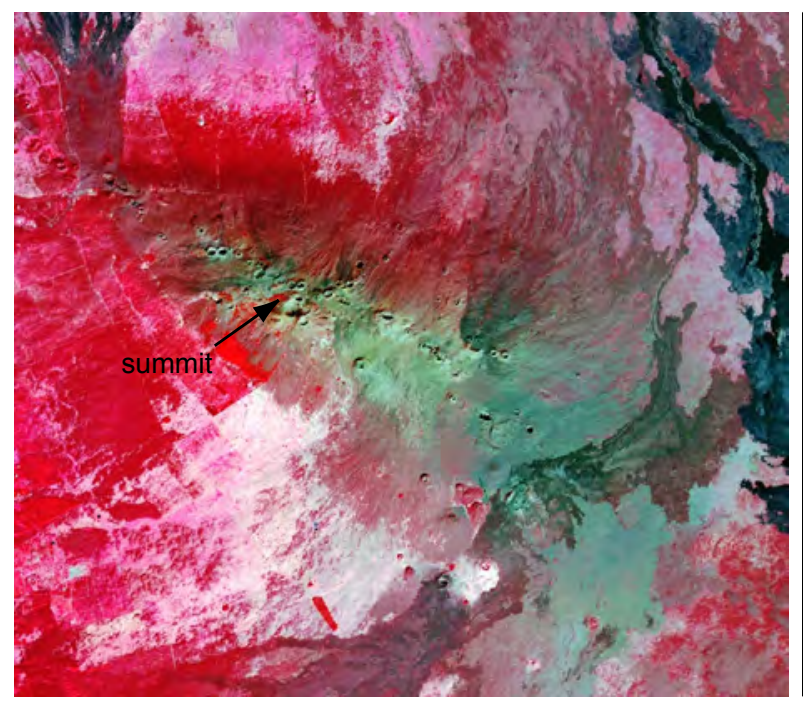

0

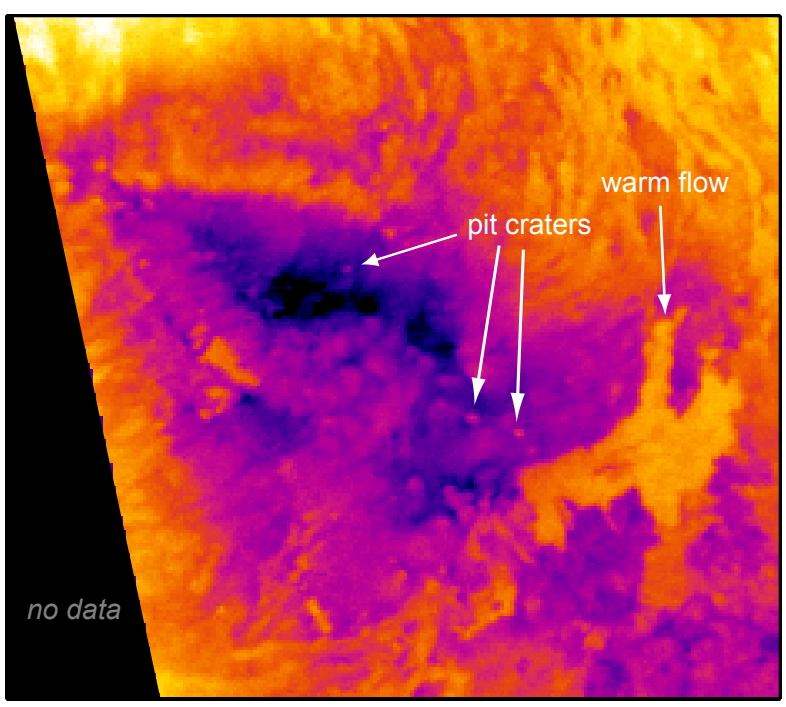

$3 \mathrm{~km}$

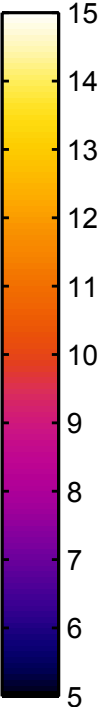

Figure 15. ASTER VNIR (visible and near-infrared) image (left) and surface kinetic temperature map (right) of Hualālai Volcano. The VNIR image was taken on January 17, 2005. The thermal map is an average of 16 individual ASTER surface kinetic temperature images collected between 2000 and 2010.
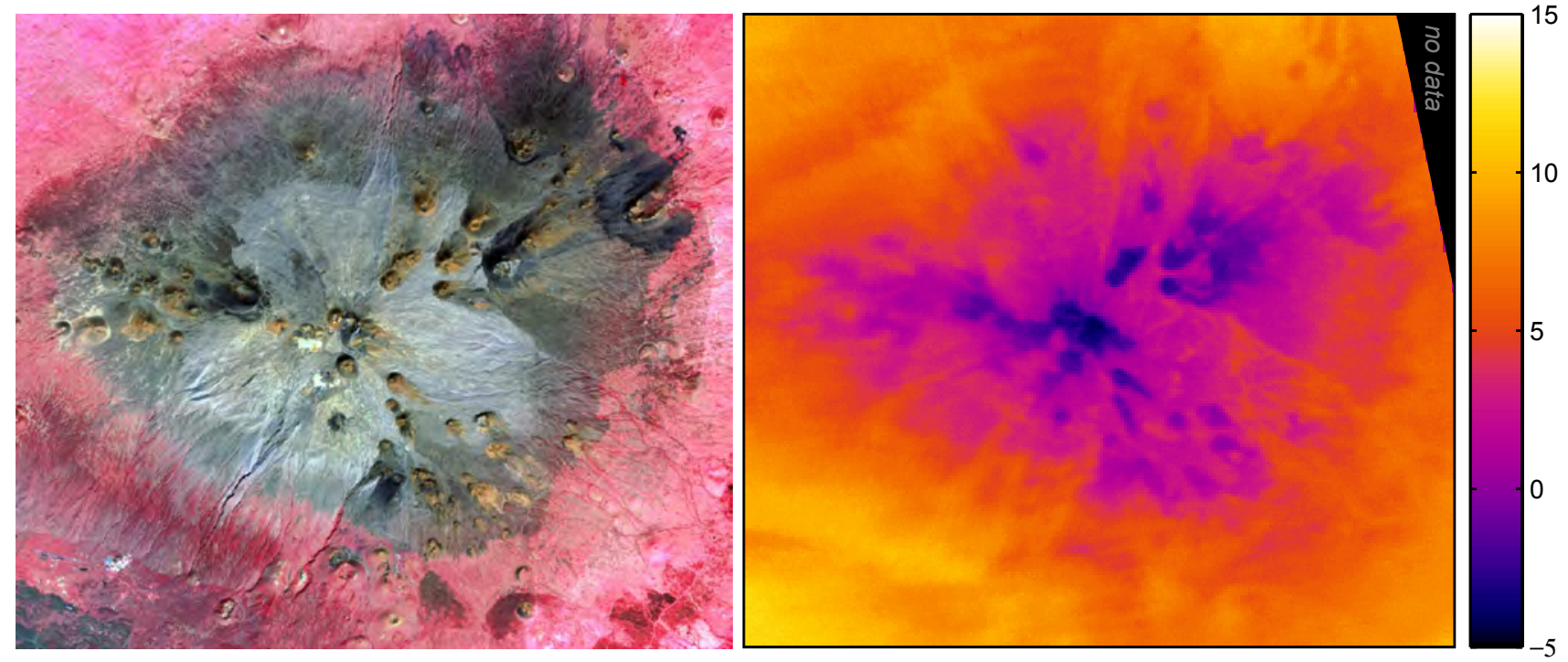

0 $3 \mathrm{~km}$

Figure 16. ASTER VNIR (visible and near-infrared) image (left) and surface kinetic temperature map (right) of Mauna Kea Volcano. The VNIR image was taken on December 5, 2000. The thermal map is an average of 21 individual ASTER surface kinetic temperature images collected between 2000 and 2010. 


\section{Interpretation}

Overall, the thermal anomalies found in this study are associated with thermal areas known from previous work, including Casadevall and Hazlett (1983), Fischer and others (1964), and Macdonald (1955). No alarming or potentially precursory activity was identified in this study. The only new thermal activity observed was that associated with the ongoing (since 2008) eruption in Halema'uma'u.

\section{Kīlauea}

A prominent feature in Kìlauea's caldera is the set of arcuate linear thermal anomalies (K5-K4-K6-K12) that seem to trace a concentric circle immediately within the caldera walls. This circular set of thermal anomalies corresponds with whitish alteration and deposition on the ground surface and spots of active steaming, in a pattern similar to that mapped by Macdonald (1955). Macdonald attributed this circular feature to scarps from the 1800 s that, albeit buried, still serve as pathways for rising gas. Fischer and others (1964) show thermal features similar to those on the Macdonald map and to our own. Given the similarity of our map with Macdonald's, we believe this set of thermal anomalies represents the same feature and is related to gas rising along buried historic intracaldera scarps.

It is not clear why the hotspot in the north caldera (K4) has one of the highest pixel-integrated temperatures within the caldera (fig. 4). Macdonald (1955) notes that this is close to the location of Perret's cone, a notable steam vent active in the early 1900s (Jaggar, 1947) and probably earlier. Holcomb
(1987) locates the Observatory vent (his crater of Lua Pele), which fed flows on the summit shield before the caldera collapse around 1500 C.E. (Swanson, 2008), just south of this area. Ellis (1825) noted that lava lake activity was present in the north caldera during his visit, and lava lake activity here probably continued into the mid-1800s. More recently, an area of persistent subsidence has been recorded by interferometric synthetic aperture radar imagery (InSAR) in this northern portion of the caldera (Poland, 2006). This area may thus represent an area of focused activity and shallow magma storage. Alternatively, it may be an area of intersecting cracks that facilitate gas rise; note that lines of high temperatures extend both northeast and southwest from K4.

The Halema'uma'u thermal anomaly (K9) is interesting in that elevated temperatures are present across the crater floor, walls, and rim, forming an expansive thermal area similar to what was shown in Fischer and others (1964). This is in contrast to the other thermal areas in the caldera, which are less expansive. Given that Halema'uma' $u$ has been the focus of most historical activity in the caldera, perhaps because the shallow magma reservoir at Kîlauea's summit is situated in the Halema'uma'u area (Cervelli and Miklius, 2003), it would be expected to be a significant and large thermal area. Residual heat in the 1967-68 lava lake in Halema'uma'u may also account for much of the elevated temperatures.

The Kîlauea Iki thermal anomaly (K7) is clearly due to residual heat within the 122-m-deep 1959 lava lake (Richter and others, 1970), which remained partly molten through the 1990s. The highest pixel-integrated temperatures occur at the west end of the lava lake near the 1959 vent, which appears to correspond with the scarp separating the shallow western

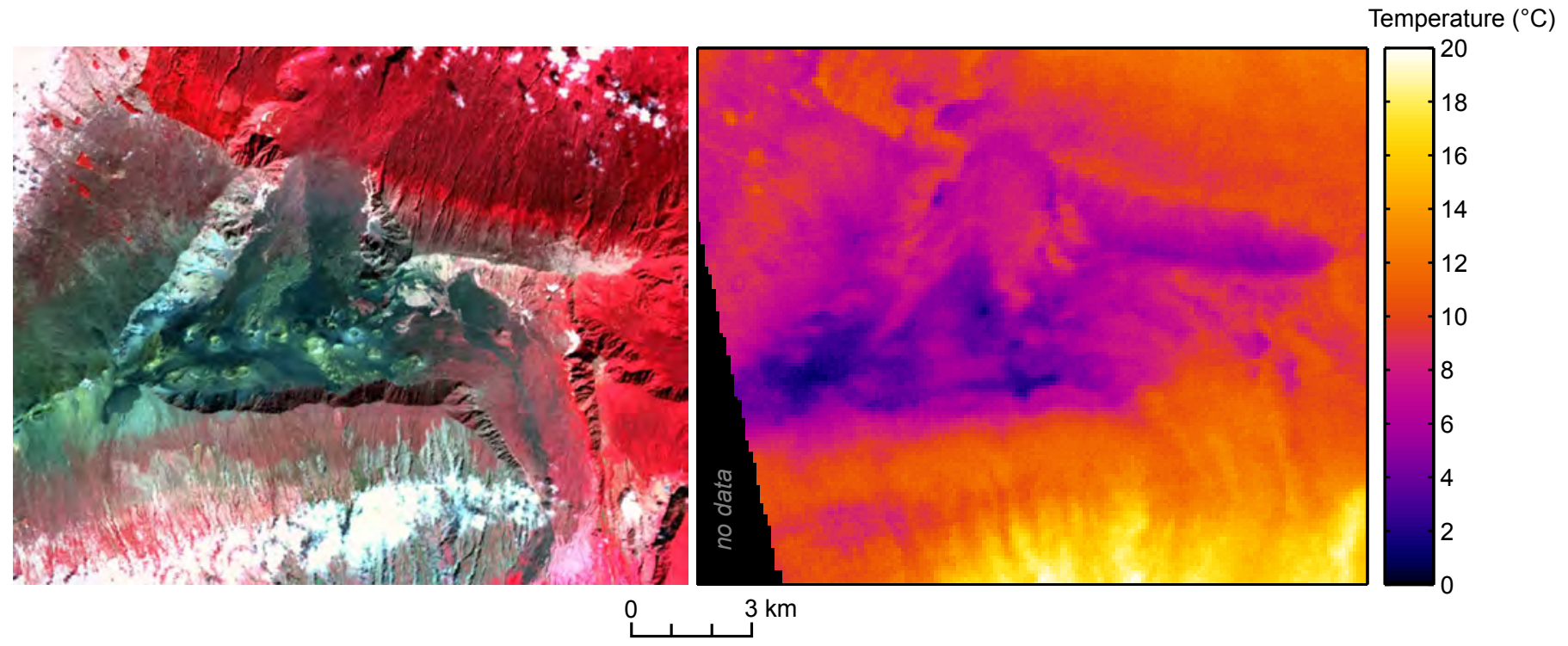

Figure 17. ASTER VNIR (visible and near-infrared) image (left) and surface kinetic temperature map (right) of Haleakalā Volcano. The VNIR image was taken on January 28, 2003. The thermal map is an average of 8 individual ASTER surface kinetic temperature images collected between 2002 and 2010. 
portion of the prelake crater and the deeper eastern portion (Richter and others, 1970). Thus, as in Kîlauea's caldera, here also a buried scarp may control gas rise. Whereas the lava lake has retained significant heat through the years, the Pu'u Pua' $i$ cone (fig. 3) shows no elevated thermal signature. Fischer and others (1964) showed that the cone was very warm three years after the eruption. The faster cooling of the cone, compared to the lava lake, is probably due to the higher permeability of the cinder and spatter cone, allowing efficient penetration by rainwater.

\section{Mauna Loa}

Like that of Killauea, Mauna Loa's summit caldera also shows a set of arcuate, linear thermal anomalies (M2-M3M7-M8-M9) that appear to form a concentric oval within the caldera walls (figs. 11, 12). The western side of this oval (M2-M3) follows the 1975 fissure, but we are not aware of any fissures or structures associated with the east side (M7M8-M9). We propose that this oval set of thermal anomalies has the same origin as the more circular one in Killauea and is related to buried scarps and/or faults that channel rising gases to the surface. It is reasonable to think that the 1975 fissure exploited one of these planes as it cut to the surface.

Corroborating the idea that the M2-M3-M7-M8-M9 oval of thermal anomalies lies above a buried scarp or fault plane, we note that the arcuate M10 anomaly (fig. 12) corresponds precisely with the south wall of the deepest portion of the caldera mapped by the U.S. Exploring Expedition in 1841 (fig. 18; Wilkes, 1845). This deeper portion of the caldera persisted through the late 1800s (Alexander, 1888) but was buried by the early 1900s.

\section{Conclusions}

This study was meant to create an accurate picture of baseline thermal activity on Hawaiian volcanoes, to help confirm or refute any possible precursory thermal activity that might be identified in the future. The specific conclusions of this study are as follows:

\section{General Results}

- No alarming or potentially precursory thermal activity was identified during this study period.

- Thermal anomalies present on lava flows are normally associated with whitish alteration and deposition due to active steaming, making identification of thermal areas possible with the naked eye.

- Buried scarps in Kīlauea and Mauna Loa summit calderas appear to provide pathways for rising gas, producing arcuate linear thermal anomalies on the caldera floor that are concentric to the caldera walls.

\section{Kīlauea}

- Thermal areas on the floor of Kìlauea's caldera are similar to those mapped in previous studies going back to the 1950 s, attesting to the stability of the shallow thermal structure of the caldera.

- Although the ongoing (since 2008) eruption of Halema'uma' $u$ has produced a prominent thermal anomaly, these data show no evidence of any thermal changes preceding the eruption.

\section{Mauna Loa}

- Mauna Loa is characterized by several arcuate, concentric thermal anomalies in the summit caldera and a large, prominent thermal anomaly at Sulphur Cone.

- At least one of the arcuate thermal anomalies in the summit caldera corresponds with a buried scarp, which likely channels rising gases, and the other arcuate thermal anomalies may also be related to buried scarps or faults.

- No detectable thermal change was measured on Mauna Loa associated with the 2002-2004 inflation.

\section{Hualālai}

- Thermal anomalies exist in several small pit craters. We suspect that these are not related to magmatic activity, but the areas deserve further study.

\section{Mauna Kea and Haleakalā}

- No detectable thermal areas were observed on these volcanoes.

\section{Limitations and Future Work}

The greatest limitation of this study is the large pixel size (90 $\mathrm{m}$ ) of the ASTER images, which can mute temperature contrast significantly. The low temporal resolution of ASTER data (16-day minimal interval) also limits the ability to detect changes. This study should be considered just a first, rough step in a comprehensive characterization of thermal behavior at Hawai'i's active volcanoes. The potential future HyspIRI mission of the National Aeronautics and Space Administration (NASA) may reduce these limitations by improving upon the pixel size $(60 \mathrm{~m})$ and possibly the temporal resolution. Building upon these spaceborne data, future work should include aerial images using a calibrated thermal camera, as well as detailed mapping of temperature sources using ground-based instruments such as thermocouples and radiometers. Areas of concern or interest would also benefit from long-term, continuous monitoring with fixed thermal cameras or thermocouples. 
A

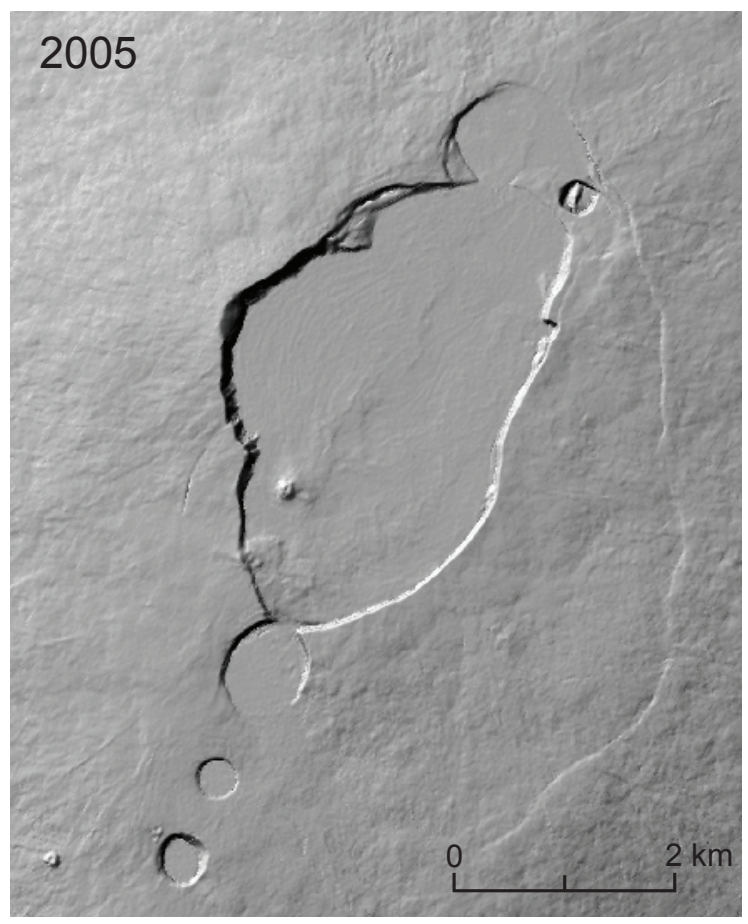

B

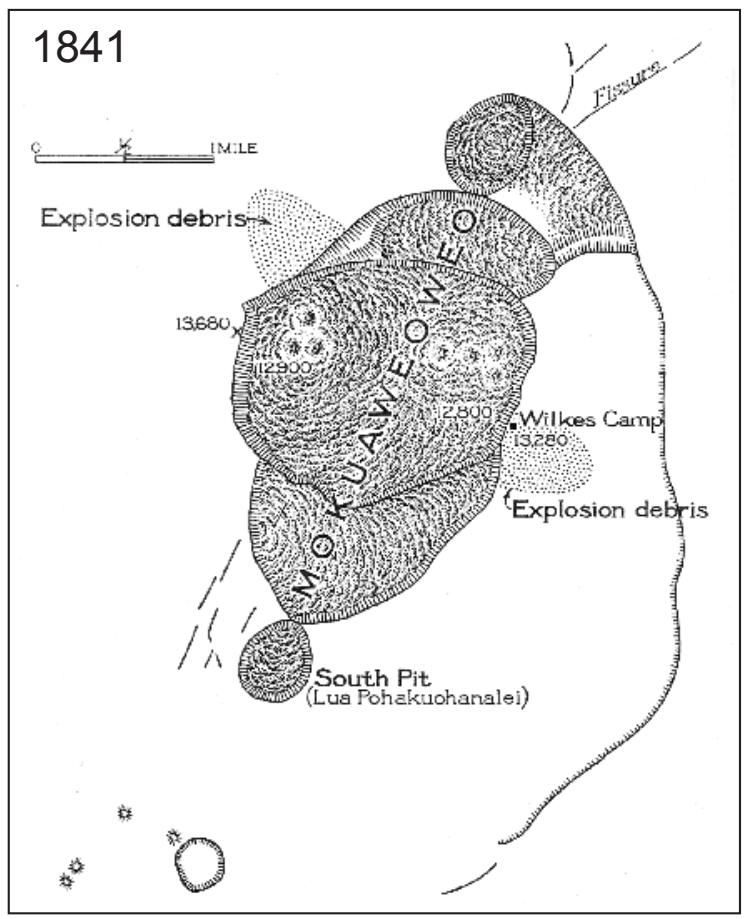

Figure 18. Current and past topography at Moku'āweoweo caldera, Mauna Loa summit. $A$, Shaded relief map from 2005, showing that the caldera floor is relatively flat. $B$, Sketch map from U.S. Exploring Expedition in 1841 (Wilkes, 1845) showing that a large north-facing scarp spanned the south portion of the caldera. This scarp corresponds with the position of the M10 thermal area. Map elevations are in feet.

\section{Acknowledgments}

We thank Michael Poland (Hawaiian Volcano Observatory; HVO) for assistance with obtaining ASTER data and for sharing InSAR data. Frank Trusdell (HVO) noted the correspondence between the Wilke's Expedition mapping and the current thermal anomalies on Mauna Loa and provided other helpful information about Mauna Loa. Reviews by Rick Wessels (Alaska Volcano Observatory) and Don Swanson (HVO) improved the manuscript significantly.

\section{References}

Alexander, J.M., 1888, On the summit crater in October, 1885, and its survey: American Journal of Science, v. 136, p. 35-39.

Amelung, F., Yun, S.-H.,Walter, T.R., Segall, P., and Kim, S.-W., 2007, Stress control of deep rift intrusion at Mauna Loa Volcano, Hawaii: Science, v. 316, p. 1026-1030.

Ballestracci, R., and Nougier, J., 1984, Detection by infrared thermography and modeling of an icecapped geothermal system in Kerguelen Archipelago: Journal of Volcanology and Geothermal Research, v. 20, p. 85-99.
Birnie, R.W., 1973, Infrared radiation thermometry of Guatemalan volcanoes: Bulletin of Volcanology, v. 37, p. 1-36.

Bonaccorso, A., Calvari, S., Garfì, G., Lodato, L., and Patanè, D., 2003, Dynamics of the December 2002 flank failure and tsunami at Stromboli volcano inferred by volcanological and geophysical observations: Geophysical Research Letters, v. 30, no. 18, 1941-1944, doi: 10.1029/2003GL017702.

Casadevall, T.J., and Hazlett, R.W., 1983, Thermal areas on Kilauea and Mauna Loa volcanoes, Hawaii: Journal of Volcanology and Geothermal Research, v. 16, p. 173-188.

Cervelli, P.F., and Miklius, A., 2003, The shallow magmatic system of Kilauea Volcano, in Heliker, C., Swanson, D.A., and Takahashi, T.J., eds., The Pu 'u 'O'o-Kupaianaha eruption of Kilauea Volcano, Hawaii; the first 20 years: U.S. Geological Survey Professional Paper 1676, p. 149-163.

Chiodini, G., Vilardo, G., Augusti, V., Granieri, D., Caliro, S., Minopoli, C., and Terranova, C., 2007, Thermal monitoring of hydrothermal activity by permanent infrared automatic stations - results obtained at Solfatara di Pozzuoli, Campi Flegrei (Italy): Journal of Geophysical Research, v. 112, no. B12206, doi:10.1029/2007JB005140.

Connor, J.J., 1979, Geochemistry of ohia and soil lichen, Puhimau thermal area, Hawaii: Science of the Total Environment, v. 12:, p. 241-250. 
Eichelberger, J.C., Heiken, G., Widdicombe, R., Wright, D., Keady, C.J., and Cobb, D.D., 1976, New fumarolic activity on Mt. Baker; observations during April through July, 1975: Journal of Volcanology and Geothermal Research, v. 1, p. 35-53.

Ellis, William, 1825, Narrative of a tour through Hawaii, or, Owhyhee: London, H. Fisher, Son, and P. Jackson, 264 p. [Reprinted 1963 as Journal of William Ellis by the Advertiser Publishing Co., Ltd., Honolulu, 342 p.]

Fischer, W.A., Moxham, R.M., Polcyn, F., and Landis, G.H., 1964, Infra-red surveys of Hawaiian volcanoes: Science, v. 146, p. 733-742.

Francis, P.W., 1979, Infra-red techniques for volcano monitoring and prediction - a review: Journal of the Geological Society of London, v. 136, p. 355-359.

Friedman, J.D., and Williams, R.S., 1968, Infrared sensing of active geologic processes: Symposium on remote sensing of environment, 5th, Ann Arbor, Michigan, 16-18 April, Proceedings, p. 787-820.

Friedman, J.D., Williams, R.S., Palmason, G., and Miller, C., 1969, Infra-red surveys in Iceland - preliminary report: U.S. Geological Survey Professional Paper 650C, p. C89-C105.

Gawarecki, S.J., Moxham, R.M., and Morgan, J.O., 1980, An infrared survey of Irazu volcano and vicinity, Costa Rica: International Symposium on Remote Sensing of the Environment, 14th, San Jose, Costa Rica, April 23-30, 1980, Proceedings. v. 3, p. 1901-1912.

Gillespie, A., Rokugawa, S., Matsunaga, T., Cothern, J.S., and Kahle, A.B., 1998, A temperature and emissivity separation algorithm for Advanced Spaceborne Thermal Emission and Reflection Radiometer (ASTER) images: IEEE (Institute of Electrical and Electronics Engineers) Transactions on Geoscience and Remote Sensing, v. 36, no. 4, p. 1113-1126.

Harris, A.J.L., and Maciejewski, A.J.H., 2000, Thermal surveys of the Vulcano Fossa fumarole field 1994-1999; evidence for fumarole migration and sealing: Journal of Volcanology and Geothermal Research, v. 102, p. 119-147.

Harris, A.J.L., Lodato, L., Dehn, J., and Spampinato, L., 2009, Thermal characterization of the Vulcano fumarole field: Bulletin of Volcanology, v. 71, p. 441-458.

Heliker, C., and Mattox, T.N., 2003, The first two decades of the $\mathrm{Pu}^{\prime} \mathrm{u}$ ' $\overline{\mathrm{O}}^{‘} \overline{\mathrm{o}}-\mathrm{K}$ Kupaianaha eruption; chronology and selected bibliography, in Heliker, C., Swanson, D.A., and Takahashi, T.J., eds., The $\mathrm{Pu}^{\prime} \mathrm{u}$ ' ${ }^{\circ}{ }^{`} \overline{\mathrm{o}}-\mathrm{K} u p a i a n a h a$ eruption of Kìlauea Volcano, Hawai' ${ }^{i}$; the first 20 years: U.S. Geological Survey Professional Paper 1676, p. 1-27.

Helz, R.T., and Thornber, C.R., 1987, Geothermometry of Kilauea Iki lava lake, Hawaii: Bulletin of Volcanology, v. 49, p. 651-668.

Hernandez, P.A., Perez, N.M., Varekamp, J.C., Henriquez, B., Hernandez, A., Barrancos, J., Padron, E., Calvo, D., and Melian, G., 2007, Crater lake temperature changes of the 2005 eruption of Santa Ana volcano, El Salvador, Central America: Pure and Applied Geophysics, v. 164, p. 25072522.

Hinkle, M.E., 1978, Helium, mercury, sulfur compounds, and carbon dioxide in soil gases of the Puhimau Thermal Area, Hawaii Volcanoes National Park, Hawaii: U.S. Geological Survey Open-File Report 78-246, 7 p.

Holcomb, R.T., 1987, Eruptive history and long-term behavior of Kilauea volcano, in Decker, R.W., Wright, T.L., and Stauffer, P.H., eds., Volcanism in Hawaii: U.S. Geological Survey Professional Paper 1350, p. 261-350.

Jaggar, T.A., 1919, Monthly Bulletin of the Hawaiian Volcano Observatory, April 1919, in Bevens, D., Takahashi, T.J., and Wright, T.L., eds., 1988, The early serial publications of the Hawaiian Volcano Observatory: Hawaii National Park, Hawaii, Hawaii Natural History Association, p. 926-927.

Jaggar, T.A., 1938, Hawaiian Volcano Observatory report for May 1938: The Volcano Letter, no. 459, p. 2-5.

Jaggar, T.A., 1947, Origin of development of craters: Geological Society of America Memoir, 21, p. 433.

Kagiyama, T., 1981, Evaluation methods of heat discharge and their applications to the major active volcanoes in Japan: Journal of Volcanology and Geothermal Research, v. 9, p. 87-97.

Kauahikaua, J., Cashman, K., Clague, D., Champion, D., and Hagstrum, J., 2002, Emplacement of the most recent lava flows on Hualalai Volcano, Hawaii: Bulletin of Volcanology, v. 64 , p. 229-253.

Kieffer, H.H., Frank, D., and Friedman, J.D., 1981, Thermal infrared surveys at Mount St. Helens - observations prior to the eruption of May 18, in Lipman, P.W., and Mullineaux, D.R., eds., The 1980 eruptions of Mount St. Helens, Washington: U.S. Geological Survey Professional Paper 1250, p. 257-278.

Lange, I.M., and Avent, J.C., 1974, Ground-based thermal infrared surveys of Mount Rainier volcano, Washington: Bulletin of Volcanology, v. 38, p. 929-943.

Lockwood, J.P., Dvorak, J.J., English, T.T., Koyanagi, R.Y., Okamura, A.T., Summers, M.L., and Tanigawa, W.R., 1987, Mauna Loa 1974-1984 - a decade of intrusive and extrusive activity, in Decker, R.W., Wright, T.L., and Stauffer, P.H., eds., Volcanism in Hawaii: U.S. Geological Survey Professional Paper 1350, p. 537-570.

Lockwood, J.P., Tilling, R.I., Holcomb, R.T., Klein, F., Okamura, A.T., and Peterson, D.W., 1999, Magma migration and resupply during the 1974 summit eruptions of Kilauea volcano, Hawai'i: U.S. Geological Survey Professional Paper 1613, $37 \mathrm{p}$.

Macdonald, G.A., 1955, Distribution of areas of pneumatolytic deposition on the floor of Kilauea caldera: The Volcano Letter, no. 528, p. 1-3.

Matsushima, N., Kazahaya, K., Saito, G., and Shinohara, H., 2003, Mass and heat flux of volcanic gas discharging from the summit crater of Iwodake volcano, Satsuma-Iwojima, Japan, during 1996-1999: Journal of Volcanology and Geothermal Research, v. 126, p. 285-301.

Miklius, A., and Cervelli, P., 2003, Vulcanology-interaction between Kilauea and Mauna Loa: Nature, v. 421, p. 229.

Miklius, A., Cervelli, P., Sako, M., Lisowski, M., Owen, S., Segal, P., Foster, J., Kamibayashi, K., and Brooks, B., 2005, 
Global positioning system measurements on the Island of Hawai'i; 1997 through 2004: U.S. Geological Survey Open-File Report 2005-1425, 46 p.

Mongillo, M.A., and Wood, C.P., 1995, Thermal infrared mapping of White Island volcano, New Zealand: Journal of Volcanology and Geothermal Research, v. 69, p. 59-71.

Moore, R.B., Clague, D.A., Rubin, M., and Bohrson, W., 1987, Hualalai Volcano; a preliminary summary of geologic, petrologic, and geophysical data, in Decker, R.W., Wright, T.L., and Stauffer, P.H., eds., Volcanism in Hawaii: U.S. Geological Survey Professional Paper 1350, p. 571-585.

Moxham, R.M., 1970, Thermal features at some Cascade volcanoes at observed by aerial infra-red surveys: Bulletin of Volcanology, v. 34, p. 77-106.

Moxham, R.M., Crandell, D.R., and Marlett, W.E., 1965, Thermal features at Mount Rainier, Washington, as revealed by infra-red surveys: U.S. Geological Survey Professional Paper 525-D, p. 93-100.

Neal, C.A., and Lockwood, J.P., 2003, Geologic map of the summit region of Kilauea Volcano, Hawaii: U.S. Geological Survey Geologic Investigations Series I-2759, scale 1:24,000.

Patrick, M., and Orr, T., 2011, Rootless shield and perched lava pond collapses at Kilauea volcano, Hawaii: Bulletin of Volcanology, doi 10.1007/s00445-011-0505-9.

Patrick, M., Orr, T., Wilson, D., Dow, D., and Freeman, R., 2011, Cyclic spattering, seismic tremor and surface fluctuation in a perched lava channel, Kilauea volcano, Hawaii: Bulletin of Volcanology, doi 10.1007/s00445-010-0431-2, www.springerlink.com/content/t7v6p4r5r02t3706.

Poland, M., 2006, InSAR observations of surface deformation associated with volcano-tectonic activity at Kilauea and Mauna Loa volcanoes, Hawaii [abs.]: Eos (American Geophysical Union Transactions), v. 87(52), Fall meeting supplement, abs. G53A-0873

Poland, M., Miklius, A., Orr, T., Sutton, A.J., Thornber, C., and Wilson, D., 2008, New episodes of volcanism at Kilauea volcano, Hawaii: Eos (American Geophysical Union Transactions), v. 89, no.5, p. 37-38.

Richter, D.H., Eaton, J.P., Murata, K.J., Ault, W.U., and Krivoy, H.L., 1970, Chronological narrative of the 1959-1960 eruption of Kilauea Volcano, Hawai' $i$, in The 1959-1960 eruption of Kīlauea Volcano, Hawai'i: U.S. Geological Survey Professional Paper 537-E, p. E1-E73.

Sherrod, D.R., Hagstrum, J.T., McGeehin, J.P., Champion, D.E., and Trusdell, F.A., 2006, Distribution, ${ }^{14} \mathrm{C}$ chronology, and paleomagnetism of latest Pleistocene and Holocene lava flows at Haleakala volcano, Island of Maui, Hawai' $i$; a revision of lava flow hazard zones: Journal of Geophysical Research, v. 111, B05205, doi:10.1029/2005JB003876.
Shimozuru, D., and Kagiyama, T., 1978, A newly devised infra-red ground scanner and its application to geothermal research in volcanoes: Journal of Volcanology and Geothermal Research, v. 4, p. 251-264.

Skinner, B.J., 1970, A sulfur flow on Mauna Loa: Pacific Science, v. 24, p. 144-145.

Swanson, D.A., 2008, Hawaiian oral tradition describes 400 years of volcanic activity at Kilauea: Journal of Volcanology and Geothermal Research, v. 176, p. 427-431.

Swanson, D.A., Duffield, W.A., Jackson, D.B., and Peterson, D.W., 1979, Chronological narrative of the 1969-71 Mauna Ulu eruption of Kilauea volcano, Hawaii: U.S. Geological Survey Professional Paper 1056, 55 p.

Tabbagh, A., Tabbagh, J., and Dechambenoy, C., 1987, Mapping of the surface temperature of Mount Etna and Vulcano Island using an airborne scanner radiometer: Journal of Volcanology and Geothermal Research, v. 34, p. 79-88.

Tilling, R.I., Christiansen, R.L., Duffield, W.A., Endo, E.T., Holcomb, R.T., Koyanagi, R.Y., Peterson, D.W., and Unger, J.D., 1987, The 1972-1974 Mauna Ulu eruption, Kilauea Volcano; an example of quasi-steady-state magma transfer, in Decker, R.W., Wright, T.L., and Stauffer, P.H., eds., Volcanism in Hawaii: U.S. Geological Survey Professional Paper 1350, p. 405-469.

Wilkes, C., 1845, Narrative of the United States Exploring Expedition, during the years 1838, 1839, 1840, 1841, 1842: Philadelphia, Lea and Blanchard, 5 v.

Williams, R.S., Hasell, P.G., Sellman, A.N., and Smedes, H.W., 1976, Thermographic mosaic of Yellowstone National Park: Photogrammetric Engineering and Remote Sensing, v. 42, p. 1315-1324.

Wilson, D., Elias, T., Orr, T., Patrick, M., Sutton, A.J., and Swanson, D., 2008, Small explosion from new vent at Kîlauea's summit: Eos (American Geophysical Union Transactions), v. 89, p. 203.

Wolfe, E.W., Wise, S.W., and Dalrymple, B., 1997, The geology and petrology of Mauna Kea Volcano, Hawaii-a study of postshield volcanism: U.S. Geological Survey Professional Paper 1557, 129 p., 4 plates.

Yamaguchi, Y., Kahle, A.B., Tsu, H., Kawakami, T., and Pniel, M., 1998, Overview of Advanced Spaceborne Thermal Emission and Reflection Radiometer (ASTER): IEEE Transactions on Geoscience and Remote Sensing, v. 36, p. 1062-1071.

Yokoyama, I., 1964, Seismometrical observation of the 1962 eruption of Volcano Tokati, Hokkaido, Japan: Bulletin of Volcanology, v. 27, p. 217-223.

Yuhara, K., Ehara, S., and Tagomori, K., 1981, Estimation of heat discharge rates using infradred measurements by a helicopter-borne thermocamera over the geothermal areas of Unzen volcano, Japan: Journal of Volcanology and Geothermal Research, v. 9, p. 99-109. 
Produced in the Menlo Park Publishing Service Center, California Manuscript approved for publication, July 6, 2011

Text edited by Peter H. Stauffer

Layout and design by Stephen L. Scott 


\section{대대}

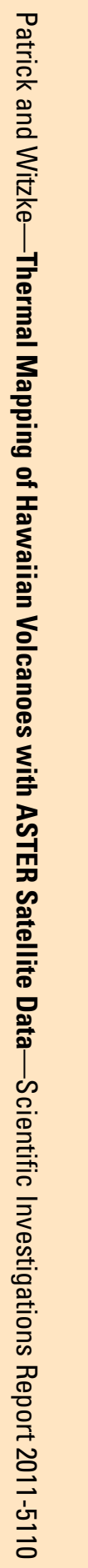

